\title{
Buku Ajar \\ Etika Bisnis Dan Profesi
}

Disusun oleh:

Dr. SIGIT HERMAWAN, SE., M.Si

NUR RAVITA HANUN, SE., MA

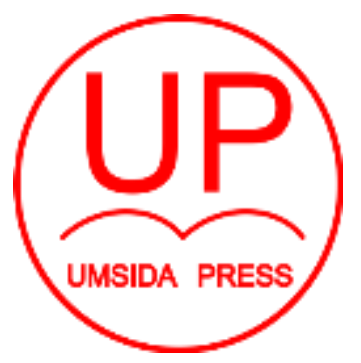

Diterbitkan oleh

\section{UMSIDA PRESS}

Jl. Mojopahit 666 B Sidoarjo

ISBN: 978-602-5914-33-1

Copyright(C2018.

Authors

All rights reserved 
BUKU AJAR

\section{ETIKA BISNIS DAN PROFESI}

\section{Penulis :}

Dr. SIGIT HERMAWAN, SE., M.Si

NUR RAVITA HANUN, SE., MA

\section{ISBN :}

978-602-5914-33-1

\section{Editor :}

Septi Budi Sartika, M.Pd

M. Tanzil Multazam, S.H., M.Kn.

\section{Copy Editor :}

Fika Megawati, S.Pd., M.Pd.

Design Sampul dan Tata Letak :

Mochamad Nashrullah, S.Pd

\section{Penerbit :}

UMSIDA Press

\section{Redaksi :}

Universitas Muhammadiyah Sidoarjo

Jl. Mojopahit No 666B

Sidoarjo, Jawa TImur

Cetakan pertama, Agustus 2018

(C) Hak cipta dilindungi undang-undang

Dilarang memperbanyak karya tulis ini dengan suatu apapun

tanpa ijin tertulis dari penerbit. 


\section{KATA PENGANTAR}

\section{Assalamu'alaikum Wr Wb}

Segala puji penulis panjatkan kehadirat Allah SWT yang telah melimpahkan segala rahmat, taufiq dan hidayah-Nya atas karunia masa lalu, saat ini, dan akan datang serta atas tersusunnya buku "ETIKA BISNIS DAN PROFESI" ini.

Buku ini disusun dengan maksud untuk memberikan referensi pada matakuliah "ETIKA BISNIS DAN PROFESI". Matakuliah ini termasuk baru dibanding dengan matakuliah akuntansi lainnya yang ada di kurikulum Program Studi Akuntansi. Oleh karena itu belum banyak buku etika bisnis dan profesi yang dapat diacu oleh dosen dan mahasiswa akuntansi..

Buku ETIKA BISNIS DAN PROFESI ini akan terdiri dari dua bagian, yakni etika bisnis secara umum dan etika profesi akuntan. Dengan demikian, proses pembelajaran yang dilakukan akan terdiri dari dua bagian penting, yakni sebelum Ujian Tengah Semester (UTS) berisi tentang etika bisnis secara umum dan setelah UTS akan berisi tentang etika profesi di bidang akuntansi. Buku ini terdiri dari Sembilan bab, yang dapat diberikan dalam 14 kali pertemuan karena ada beberapa bab yang cukup berat pembahasannya sehingga harus diberikan dalam dua kali sesi pertemuan. Pada setiap bab di buku ini akan terdiri dari pendahuluan, capaian pembelajaran, materi yang terdiri dari sub bab, dan rangkuman.

Penulis berharap semoga buku ini dapat bermanfaat bagi para mahasiswa dan pembaca pada umumnya. Penulis menerima kritik dan saran yang akan lebih menyempurnakan buku ini. Ucapan terima kasih yang tulus penulis sampaikan kepada rekan-rekan kami yang telah memberikan inspirasi, rekan sesama tenaga pengajar, para mahasiswa, guru dan dosen 
kami, serta Penerbit UMSIDA Press yang bersedia menerbitkan buku ini.

Sidoarjo, Juli 2018

Dr. Sigit Hermawan, SE., M.Si

Nur Ravita Hanun, SE., M.A. 


\section{DAFTAR ISI}

Cover

Identitas Buku

Kata Pengantar

Daftar Isi

Bab I. Pengertian Etika dan Teori Etika
A. Pendahuluan
B. Pengertian Etika
C. Tujuan Etika dan Norma
D. Teori-Teori Etika
E. Rangkuman

Bab II. Etika Bisnis dan Lingkungan
A. Pendahuluan
B. Etika Bisnis dan Tanggung Jawab Sosial
C. Tanggung Jawab Kepada Pelanggan dan Karyawan
D. Tanggung Jawab Kepada Pemegang Saham dan Kreditor
E. Tanggunh Jawab Kepada Lingkungan dan Komunitas
F. Biaya Untuk Memenuhi Tanggung Jawab Sosial
G. Pembahasan Kasus Etika Bisnis
H. Rangkuman

\section{Bab III. Etika Bisnis dan Good Corparate Governance}
A. Pendahuluan
B. Pengertian Good Corporate Governance
C. Pilar Good Governancer
D. Prinsip Good Corporate Governance
E. Keterkaitan Antara Etika Bisnis dan GCG
F. Rangkuman

Bab IV. Etika Bisnis dan Corporate Social Responsibility
A. Pendahuluan
B. Definisi Corporate Social Responsibility (CSR) 

C. Manfaat CSR Bagi Perusahaan dan Organisasi
D. Indikator Keberhasilan CSR
E. Etika Bisnis dan CSR
F. Rangkuman

\section{Bab V. Etika Bisnis dan Good Corparate Governance}
A. Pendahuluan
B. Pengertian Good Corporate Governance
C. Pilar Good Governancer
D. Prinsip Good Corporate Governance
E. Keterkaitan Antara Etika Bisnis dan GCG
F. Rangkuman

\section{Bab VI. Etika Bisnis dan Islam}
A. Pendahuluan
B. Sumber Islam
C. Etika Bisnis dan Tanggung Jawab Sosial dalam Islam
D. Islam dan Aturan Bisnis yang Beretika
E. Rangkuman

Bab VII. Etika Profesi Akuntan
A. Pendahuluan
B. Prinsip Etika Profesi Ikatan Akuntan Indonesia
C. Tanggung Jawab Profesi
D. Kepentingan Publik
E. Integritas
F. Obyektivitas
G. Kompetensi dan Kehati-Hatian Profesional
H. Kerahasiaan
I. Perilaku Profesional
J. Standar Teknis
K. Rangkuman

\section{Bab VIII. Etika Profesi Akuntan Sektor Publik}
A. Pendahuluan
B. Pengertian Akuntansi Sektor Publik (ASP) 

C. Cakupan Bidang Utama
D. Dimensi Akuntabilitas Publik
E. Prinsip Etika Profesi bagi Akuntan Publik
F. Rangkuman

\section{Bab XI.Etika Profesi Akuntan Manajemen dan Keuangan}
A. Pendahuluan
B. Pengertian dan Lingkup Akuntansi Manajemen \& Akuntansi Keuangan
C. Tanggung Jawab Manajemen
D. Standar Kode Etik untuk Praktisi Akuntan Manajemen dan Manajemen Keuangan
E. Rangkuman

\section{Bab X.Etika Profesi Akuntan Pajak}
A. Pendahuluan
B. Pengertian Akuntansi Perpajakan
C. Kewajiban dan Hak Konsultan Pajak
D. Kode Etik Konsultan Pajak Indonesia
E. Rangkuman

\section{Daftar Pustaka}

\section{Biodata Penulis}




\section{BAB I}

\section{PENGERTIAN ETIKA BISNIS}

\section{TUJUAN INSTRUKSIONAL}

Dengan membaca bab ini, mahasiswa diharapkan mampu untuk :

1. Memahami pengertian etika

2. Menjelaskan prinsip etika bisnis

3. Menjelaskan Hakikat mata kuliah etika bisnis

4. Menjelaskan Konsep Etika

5. Tujuan dan Fungsi Etika Bisnis

6. Contoh Pelanggaran Etika Bisnis

\section{A. PENDAHULUAN}

Perilaku yang baik dan beretika sangat diperlukan dalam segala aspek kehidupan termasuk dalam berbisnis. Perilaku beretika dalam bisnis kelihatan janggal oleh beberapa pihak karena banyaknya praktik yang tidak baik dalam berbisnis. Bahkan banyak juga pameo yang menyatakan bahwa bisnis yang beretika tidak akan cepat mendatangkan keuntungan bahkan mengalami kerugian. Padahal pameo tersebut tidak benar. Perilaku beretika dalam bisnis akan mendatangkan keuntungan bahkan lebih bersifat jangka panjang dibandingkan dengan perilaku bisnis yang tidak beretika.

Pada bab ini akan dibahas tentang pengertian dan konsep etika bisnis, peran etika bisnis, prinsip etika bisnis, 


\section{B. PENGERTIAN ETIKA BISNIS}

Menurut penulis bahwa etika bisnis adalah suatu tindakan dalam berbisnis yang memperhatikan dan menggunakan aspek norma, moralitas, dan agama. Dengan memperhatikan pengertian tersebut ada bebeapa kata kunci yang penting, yakni berbisnis, norma, moralitas, dan agama. Berbisnis yang dimaksud adalah melakukan kegiatan usaha baik yang dilakukan secara individual perseorangan atau dalam bentuk usaha atau perusahaan. Sementara itu berdasarkan norma, moralitas, dan agama adalah tindakan yang sesuai peraturan dan kaidah-kaidah yang sejalan dengan aturan-aturan dan hukum yang berlaku termasuk hukum agama.

Dalam sebuah perusahaan atau berwirausaha, etika bisnis dapat menjadi pedoman atau standar bagi karyawan atau pelaku usaha dalam menjalankan aktivitas kesehariannya. Begitu juga ketika sebuah perusahan atau pelaku usaha melakukan transaksi bisnis di sebuah masyarakat maka norma, moral, dan agama harus benar-benar digunakan dalam setiap praktiknya. Jika tidak maka akan menganggu kelangsungan hidup perusahaan atau usaha baik secara langsung ataupun tidak dan baik dalam jangka pendek maupun dalam jangka panjang kelak.

Sementara itu terdapat banyak versi definisi etika bisnis dari berbagai pihak, dan berikut adalah beberapa definisi etika bisnis : (Haurissa dan Praptiningsih, 2014) 
1. Menurut Laura Nash (1990), etika bisnis sebagai studi mengenai bagaimana norma moral personal diaplikasikan dalam aktivitas dan tujuan perusahaan (dalam Sutrisna, 2010).

2. Menurut Griffin dan Ebert (2007), etika bisnis adalah istilah yang biasanya berkaitan dengan perilaku etis atau tidak etis yang dilakukan oleh manajer atau pemilik suatu organisasi.

3. Menurut Velasques (2005), etika bisnis merupakan studi yang dikhususkan mengenai moral yang benar dan salah. Studi ini berkonsentrasi pada standar moral sebagaimana diterapkan dalam kebijakan, institusi, dan perilaku bisnis.

4. Menurut Irham Fahmi (2013), etika bisnis adalah aturan-aturan yang menegaskan suatu bisnis boleh bertindak dan tidak boleh bertindak, dimana aturan-aturan tersebut dapat bersumber dari aturan tertulis maupun aturan yang tidak tertulis. Dan jika suatu bisnis melanggar aturan-aturan tersebut maka sangsi akan diterima. Dimana sangsi tersebut dapat berbentuk langsung maupun tidak langsung.

Sementara itu mengutip Meilina (2016) bahwa bisnis yang beretika harus dilihat dari tiga sudut pandang yaitu ekonomi, hukum, dan moral (Bertens (2013:25). Berikut penjelasannya :

1. Berdasarkan sudut pandang ekonomi, bisnis yang baik adalah bisnis yang menghasilkan keuntungan tanpa merugikan orang lain.

2. Berdasarkan sudut pandang hukum bahwa bisnis yang baik adalah bisnis yang tidak melanggar aturan-aturan hukum. 
3. Berdasarkan sudut pandang moral bahwa bisnis yang baik adalah bisnis yang sesuai dengan ukuran-ukuran moralitas.

\section{PERAN ETIKA BISNIS}

Sebagaimana definisi yang diberikan oleh banyak ahli tentang etika bisnis maka menurut penulis bahwa etika bisnis akan berperan untuk kehidupan berbisnis yang lebih baik, lebih sehat, dan dalam konteks agama akan membawa keberkahan bagi perusahaan, pelaku usaha, dan masyarakat sekitar. Sementara itu beberapa ahli menyatakan peran etika bisnis sebagai berikut : (Haurissa dan Praptiningsih, 2014)

1. Etika harus menjadi pedoman dalam kegiatan masyarakat, dan seharusnya juga menjadi pedoman bagi pebisnis. Mana tindakan yang tepat, benar dan boleh dilakukan dalam bisnis yang diharapkan menguntungkan semua pihak yang terlibat (Satyanugraha, 2003).

2. Etika berperan sebagai penghubung pelaku bisnis. Pelayanan purna jual tentu merupakan refleksi nilai atau etika bisnis yang diterapkan perusahaan untuk menjaga loyalitas konsumennya (Tjiptono, 2005).

3. Etika juga berperan sebagai syarat utama untuk kelanggengan atau konsistensi perusahaan. Loyalitas konsumen akan dapat membantu perusahaan agar tetap bisa bertahan (Tjiptono, 2005). 
4. Untuk membangun kultur bisnis yang sehat, idealnya dimulai dari perumusan etika yang akan digunakan sebagai norma perilaku sebelum aturan (hukum) perilaku dibuat dan laksanakan, atau aturan (norma) etika tersebut diwujudkan dalam bentuk aturan hukum (Arman, 2011).

5. Sebagai kontrol terhadap individu. Pelaku dalam bisnis yaitu melalui penerapan kebiasaan atau budaya moral atas pemahaman dan penghayatan nilai-nilai dalam prinsip moral sebagai inti kekuatan suatu perusahaan dengan mengutamakan kejujuran, bertanggung jawab, disiplin, berperilaku tanpa diskriminasi (Arman, 2011).

6. Etika bisnis hanya bisa berperan dalam suatu komunitas moral, tidak merupakan komitmen individual saja, tetapi tercantum dalam suatu kerangka sosial (Arman, 2011).

\section{PRINSIP ETIKA BISNIS}

Prinsip etika bisnis berkaitan dengan hal-hal penting yang menjadi dasar pelaksanaan etika bisnis. Haurisa \& Praptiningsih (2014: 1) mengutip pendapat Keraf bahwa ada lima prinsip dalam etika bisnis yaitu :

1. Prinsip Otonomi : kemampuan seseorang bertindak berdasarkan kesadaran dirinya sendiri tanpa pengaruh dari pihak lain.

2. Prinsip Kejujuran : sifat terbuka dan memenuhi syarat-syarat bisnis. 
3. Prinsip Keadilan: bersikap sama secara objektif, rasional, dan dapat dipertanggungjawabkan.

4. Prinsip Saling Menguntungkan: tidak ada pihak yang dirugikan dalam bisnis.

5. Prinsip Integritas Moral : memenuhi standar moralitas.

Prinsip-prinsip tersebut dapat menjadi indikator untuk perusahaan yang melakukan usahanya sesuai etika bisnis. Salah satu prinsip yang tidak terpenuhi mengindikasikan adanya pelanggaran etika bisnis. Bertens (2013: 25) mengemukakan tiga ukuran moralitas dalam bisnis yang dapat digunakan untuk mengukur sudut pandang moral dan prinsip integritas moral, yaitu:

1. Hati nurani; Setiap keputusan yang diambil menurut hati nurani adalah baik. Orang yang mengambil keputusan dengan mengingkari hati nuraninya, secara tidak langsung dia juga menghancurkan integritas pribadinya

2. Kaidah emas; Kaidah emas berbunyi "hendaklah memperlakukan orang lain sebagaimana anda sendiri ingin diperlakukan" hal ini berarti, jika seseorang tidak ingin mendapat perlakuan buruk, maka jangan sampai memperlakukan orang lain dengan buruk.

3. Penilaian umum; Perilaku bisnis yang oleh masyarakat umum dinilai baik, berarti bisnis tersebut etis. Namun, jika masyarakat umum menilai bisnis tersebut tidak baik, berarti bisnis tersebut tidak etis. Hal ini disebut juga audit sosial. Teori etika 
membantu dalam menentukan penilaian etis atau tidaknya suatu perilaku. Alasan benar atau tidaknya perilaku yang dilakukan seseorang dapat didukung dengan teori etika.

\section{KONSEP ETIKA BISNIS}

Konsep etika bisnis tercermin pada corporate culture (budaya perusahaan). budaya perusahaan merupakan karakter suatu perusahaan yang mencakup pengalaman, cerita, kepercayaan dan norma bersama yang dianut oleh jajaran perusahaan. Hal ini dapat dilihat dari cara karyawannya berpakaian, berbicara, melayani tamu dan pengaturan kantor.

Dasar pemikiran:

Suatu perusahaan akan memiliki hak hidup apabila perusahaan tersebut memiliki pasar, dan dikelola oleh orangorang yang ahli dan menyenangi pekerjaannya.

Agar perusahaan tersebut mampu melangsungkan hidupnya, ia dihadapkan pada masalah:

1. Intern, misalnya masalah perburuhan

2. Ekstern,misalnya konsumen dan persaingan

3. Lingkungan, misalnya gangguan keamanan

Pada dasarnya ada 3 hal yang dapat membantu perusahaan mengatasi masalah di atas yaitu:

1. Perusahaan tersebut harus dapat menemukan sesuatu yang baru. 
2. Mampu menemukan yang terbaik dan berbeda

3. Tidak lebih jelek dari yang lain

Untuk mewujudkan hal tersebut perlu memiliki nilai-nilai yang tercermin pada:

1. Visi

2. Misi

3. Tujuan

4. Budaya organisasi

\section{E. TUJUAN DAN FUNGSI ETIKA BISNIS}

Tujuam etika bisnis adalah untuk menjalankan dan menciptakan sebuah bisnis seadil mungkin serta menyesuaikan hukum yang sudah dibuat. Selain itu, juga dimaksudkan untuk menghilangkan ketergantungan pada sebuah kedudukan individu maupun perusahaan.

Etika bisnis ini tingkatannya lebih luas jika dibanding dengan ketentuan yang sudah diatur berdasarkan hukum yang berlaku, bahkan jika dibandingkan dengan standar minimal dari ketentuan hukum maka etika bisnis menjadi standar atau ukuran yang lebih tinggi. Hal ini dikarenakan, dalam kegiatan berbisnis tidak jarang kita jumpai adanya bagian abu-abu dan tidak diatur berdasarkan ketentuan hukum.

Adapun fungsi etika bisnis diantaranya adalah dapat mengurangi dana yang diakibatkan dari pencegahan yang 
kemungkinan terjadinya friksi atau perpecahan, baik dari intern perusahaan itu sendiri maupun ekstern.

Selain itu, dalam penerapan etika bisnis ini juga berfungsi untuk membangkitkan motivasi pekerja agar terus meningkat, melindungi prinsip dalam kebebasan berdagang atau berniaga, serta dapat meciptakan keunggulan dalam bersaing.

Secara umum, suatu tindakan perusahaan yang kurang etis akan membuat konsumen menjadi terpancing dan pada akhirnya muncullah sebuah tindakan pembalasan. Seperti contoh adanya larang beredarnya suatu produk, gerakan pemboikotan, dan yang sejenisnya, maka yang terjadi adalah penurunan nilai jual dan juga perusahaan.

Hal ini tentu berbeda dengan suatu perusahaan yang menghargai adanya etika bisnis, pasti akan mendapatkan peringkat kepuasan yang lebih tinggi. Nah, sampai disini pembahasan kita tentang pengertian etika bisnis, selamat untuk Anda yang berani masuk dalam dunia bisnis dan tentunya dengan menjunjung tinggi adanya etika bisnis.

\section{F. Contoh Pelanggaran Etika Bisnis}

1. Enron - Praktik akuntansi dan manipulasi pasokan energi yang diajukan menurunkan perusahaan ini. Enron: Orang-orang Tercerdas di Ruang adalah film dokumenter yang sangat bagus yang menjelaskan skandal tersebut. 
2. Monsanto - Monsanto telah dikritik karena ukurannya yang mega. Kritikus khawatir bahwa mereka mengambil alih persediaan makanan dan juga menciptakan masalah lingkungan yang negatif. Simak Kode Etik Monsanto untuk Chief Executive dan Senior Financial Officers.

3. Arthur Andersen - Arthur Andersen dikenal karena praktik audit yang tidak etis. Simak Kejatuhan Arthur Andersen untuk rincian lebih lengkap.

4. WalMart - Studi telah menunjukkan bahwa WalMart dapat menghemat uang orang tapi mungkin juga berdampak negatif pada masyarakat. Harga rendah mereka mungkin juga merugikan pemasok.Perusahaan menerima kritik saat kepemimpinan mengumumkan bahwa mereka ingin mempekerjakan karyawan yang lebih sehat dan produktif. WalMart telah dituduh anti serikat pekerja dan telah bertahan dari skandal keringat dan diskriminasi. Lihat Pernyataan WalMart Mengenai Kode Etik.

5. Seluruh negara - Perusahaan menawarkan pinjaman subprime yang kemudian mengakibatkan gagal bayar. Kritikus telah mengklaim bahwa karyawan Countrywide memberi tahu klien bahwa propertinya akan meningkat nilainya dan pinjaman mereka dapat dibiayai kembali saat nilai pasar meningkat. Nilai pasar menurun menyebabkan banyak kehilangan rumah mereka. Lihat Kode Etik di Seluruh Negara . 
6. Beechnut - Etika Beechnut dipertanyakan saat diketahui bahwa mereka menjual "jus apel” ke negara-negara asing yang mengandung sesuatu yang kurang dari jus apel. Untuk informasi lebih lanjut tentang skandal ini, lihatlah Sejarah Beechnut dan Apple Juice Scandal .

7. Strategi Starbucks - Clustering dapat memaksa perusahaan kecil keluar dari bisnis. Ada begitu banyak Starbucks di sudutsudut jalan sehingga film-film seperti Best In Show mengolokolok bagaimana mungkin ada satu Starbucks tepat di seberang jalan dari yang lain. Lihat Kode Etik Starbucks untuk CEO dan Pemimpin Keuangan.

8. Praktik Manufaktur termasuk memproduksi sepatu lepas pantai untuk menghemat uang. Nike telah menggunakan pangsa sweatshop di bidang manufaktur. Mereka mendapat kecaman atas pelanggaran hak asasi manusia.

\section{Contoh Pelanggaran Lainnya seperti:}

Praktek etika bisnis yang dihubungkan dengan moral

Uang milik perusahaan tidak boleh diambil atau ditarik oleh setiap pejabat perusahaan untuk dimiliki secara pribadi. Hal ini bertentangan dengan etika bisnis. Memiliki uang dengan cara merampas atau menipu adalah bertentangan dengan moral. Pejabat perusahaan yang sadar etika bisnis, akan melarang pengambilan uang perusahaan untuk kepentingan pribadi, Pengambilan yang terlanjur wajib dikembalikan. 
Pejabat yang sadar, disebut memiliki kesadaran moral, yakni keputusan secara sadar diambil oleh pejabat, karena ia merasa bahwa itu adalah tanggungjawabnya, bukan saja selaku karyawan melainkan juga sebagai manusia yang bermoral.

Contoh tidak memiliki kesadaran moral

Seorang berdarah dingin di jalan juanda, Jakarta yang asangat ramai itu menodong dengan clurit dan merampas harta milik seseorang. Baginya menodong itu merupakan kebiasaan dan menjadi profesinya. Apakah ada kesadaram moral bahwa perbuatan itu bertentangan dan dilarang oleh ajaran agama, hukum dan adat? Sejak kecil ia ditingggalkan oleh ibu bapaknya akibat perceraian, ia bergaul dengan anak gelandangan,pencuri. Sesudah dewasa menjadi penodong ulung. la menodong atau membunuh tanpa mengenal rasa takut atau berdosa, bahkan sudah merupakan suatu profesi.

Pelanggaran etika bisnis terhadap hukum

Sebuah perusahaan $\mathrm{X}$ karena kondisi perusahaan yang pailit akhirnya memutuskan untuk PHK kepada karyawannya. Namun dalam melakukan PHK itu, perusahaan sama sekali tidak memberikan pesangon sebagaimana yang diatur dalam UU No. 13/2003 tentang Ketenagakerjaan. Dalam kasus ini perusahaan $\mathrm{x}$ dapat dikatakan melanggar prinsip kepatuhan terhadap hukum. 
Pelanggaran etika bisnis terhadap transparansi

Sebuah Yayasan $X$ menyelenggarakan pendidikan setingkat SMA. Pada tahun ajaran baru sekolah mengenakan biaya sebesar Rp 500.000,- kepada setiap siswa baru. Pungutan sekolah ini sama sekali tidak diinformasikan kepada mereka saat akan mendaftar, sehingga setelah diterima mau tidak mau mereka harus membayar. Disamping itu tidak ada informasi maupun penjelasan resmi tentang penggunaan uang itu kepada wali murid.

Setelah didesak oleh banyak pihak, Yayasan baru memberikan informasi bahwa uang itu dipergunakan untuk pembelian seragama guru. Dalam kasus ini, pihak Yayasan dan sekolah dapat dikategorikan melanggar prinsip transparansi.

Pelanggaran etika bisnis terhadap akuntabilitas

Sebuah RS Swasta melalui pihak Pengurus mengumumkan kepada seluruh karyawan yang akan mendaftar PNS secara otomotais dinyatakan mengundurkan diri. A sebagai salah seorang karyawan di RS Swasta itu mengabaikan pengumuman dari pihak pengurus karena menurut pendapatnya ia diangkat oleh Pengelola dalam hal ini direktur, sehingga segala hak dan kewajiban dia berhubungan dengan Pengelola bukan Pengurus.

Pihak Pengelola sendiri tidak memberikan surat edaran resmi mengenai kebijakan tersebut.Karena sikapnya itu, A 
akhirnya dinyatakan mengundurkan diri. Dari kasus ini RS Swasta itu dapat dikatakan melanggar prinsip akuntabilitas karena tidak ada kejelasan fungsi, pelaksanaan dan pertanggungjawaban antara Pengelola dan Pengurus Rumah Sakit.

Pelanggaran etika bisnis terhadap prinsip pertanggungjawaban Sebuah perusahaan PJTKI di Jogja melakukan rekrutmen untuk tenaga baby sitter. Dalam pengumuman dan perjanjian dinyatakan bahwa perusahaan berjanji akan mengirimkan calon TKI setelah 2 bulan mengikuti training dijanjikan akan dikirim ke negara-negara tujuan. Bahkan perusahaan tersebut menjanjikan bahwa segala biaya yang dikeluarkan pelamar akan dikembalikan jika mereka tidak jadi berangkat ke negara tujuan. B yang terarik dengan tawaran tersebut langsung mendaftar dan mengeluarkan biaya sebanyak Rp 7 juta untuk ongkos administrasi dan pengurusan visa dan paspor. Namun setelah 2 bulan training, B tak kunjung diberangkatkan, bahkan hingga satu tahun tidak ada kejelasan. Ketika dikonfirmasi, perusahaan PJTKI itu selalu berkilah ada penundaan, begitu seterusnya. Dari kasus ini dapat disimpulkan bahwa Perusahaan PJTKI tersebut telah melanggar prinsip pertanggungjawaban dengan mengabaikan hak-hak B sebagai calon TKI yang seharusnya diberangnka ke negara tujuan untuk bekerja. 
Pelanggaran etika bisnis terhadap prinsip kewajaran

Sebuah perusahaan property ternama di Yogjakarta tidak memberikan surat ijin membangun rumah dari developer kepada dua orang konsumennya di kawasan kavling perumahan milik perusahaan tersebut. Konsumen pertama sudah memenuhi kewajibannya membayar harga tanah sesuai kesepakatan dan biaya administrasi lainnya.

Sementara konsumen kedua masih mempunyai kewajiban membayar kelebihan tanah, karena setiap kali akan membayar pihak developer selalu menolak dengan alasan belum ada ijin dari pusat perusahaan (pusatnya di Jakarta).

Yang aneh adalah di kawasan kavling itu hanya dua orang ini yang belum mengantongi izin pembangunan rumah, sementara 30 konsumen lainnya sudah diberi izin dan rumah mereka sudah dibangun semuannya.

Alasan yang dikemukakan perusahaan itu adalah ingin memberikan pelajaran kepada dua konsumen tadi karena dua orang ini telah memprovokasi konsumen lainnya untuk melakukan penuntutan segera pemberian izin pembangunan rumah. Dari kasus ini perusahaan property tersebut telah melanggar prinsip kewajaran (fairness) karena tidak memenuhi hak-hak stakeholder (konsumen) dengan alasan yang tidak masuk akal. 
Pelanggaran etika bisnis terhadap prinsip kejujuran

Sebuah perusahaan pengembang di Sleman membuat kesepakatan dengan sebuah perusahaan kontraktor untuk membangun sebuah perumahan. Sesuai dengan kesepakatan pihak pengembang memberikan spesifikasi bangunan kepada kontraktor. Namun dalam pelaksanaannya, perusahaan kontraktor melakukan penurunan kualitas spesifikasi bangunan tanpa sepengetahuan perusahaan pengembang.

Selang beberapa bulan kondisi bangunan sudah mengalami kerusakan serius. Dalam kasus ini pihak perusahaan kontraktor dapat dikatakan telah melanggar prinsip kejujuran karena tidak memenuhi spesifikasi bangunan yang telah disepakati bersama dengan perusahaan pengembang.

Pelanggaran etika bisnis terhadap prinsip empati

Seorang nasabah, sebut saja $\mathrm{X}$, dari perusahaan pembiayaan terlambat membayar angsuran sesuai tanggal jatuh tempo karena anaknya sakit parah. $X$ sudah memberitahukan kepada pihak perusahaan tentang keterlambatannya membayar angsuran, namun tidak mendapatkan respon dari perusahaan. Beberapa minggu setelah jatuh tempo pihak perusahaan langsung mendatangi $X$ untuk menagih angsuran dan mengancam akan mengambil mobil yang masih diangsur itu. 
Pihak perusahaan menagih dengan cara yang tidak sopan dan melakukan tekanan psikologis kepada nasabah. Dalam kasus ini kita dapat mengakategorikan pihak perusahaan telah melakukan pelanggaran prinsip empati pada nasabah karena sebenarnya pihak perusahaan dapat memberikan peringatan kepada nasabah itu dengan cara yang bijak dan tepat.

\section{DAFTAR PUSTAKA}

Bertens, K . 2013. Pengantar Etika Bisnis. Yogyakarta : Kanisius.

Fahmi, I . 2013. Etika Bisnis: Teori, Kasus, dan Solusi. Bandung: Alfabeta.

Haurissa, Lina Juliana, dan Maria Praptiningsih. 2014. Analisis Penerapan Etika Bisnis Pada PT. Maju Jaya di Pare Jawa TImur. AGORA. Vol 2 No 2.

http://arifwahyuandhika.blogspot.co.id/2016/10/definisi-etikabisnis-hakikat-etika.html

http://bisnisi.com/pengertian-definisi-tujuan-dan-fungsi-etikabisnis/

http://kamusbisnis.com/artikel/3-hal-yang-harus-diperhatikandalam-rencana-bisnis/

https://fahmirezamathovani.wordpress.com/2015/11/25/pengerti an-tujuan-dan-fungsi-etika-bisnis/

https://id.m.wikipedia.org/wiki/Etika_bisnis

https://id.wikipedia.org/wiki/Etika_bisnis 
http://kelompok7rismatulkaromah.blogspot.co.id/2016/06/conto h-kasus-pelanggaran-etika-bisnis.html

https://muamalatku.com/contoh-pelanggaran-etika-bisnis/

https://muhammadmaulanablog.wordpress.com/2018/03/

https://www.jurnal.id/id/blog/2017/pengertian-tujuan-dancontoh-etika-bisnis-dalam-perusahaan

http://rfihnf.blogspot.co.id/2018/03/

Meilina, Restin. 2016. Faktor Yang Mempengaruhi Pelanggaran Etika Bisnis. Akademika. Vol 14. No 2. HIm 119-126. 


\section{BAB II}

\section{TEORI ETIKA BISNIS}

\section{TUJUAN INSTRUKSIONAL}

Dengan membaca bab ini, mahasiswa diharapkan untuk mampu :

1. Menjelaskan teori - teori etika bisnis

2. Indikator Etika Bisnis

3. Model Etika dalam Bisnis

\section{A. PENDAHULUAN}

Teori etika diperlukan untuk menjelaskan praktik yang berkaitan dengan etika yang sedang berlangsung. Ada beberapa teori etika yang telah dirumuskan oleh para ahli, yakni etika deontology, etika teleologi, teori hak, dan teori keutamaan. Pada bab ini akan dijelaskan tentang teori-teori tersebut disertai dengan pembahasan tentang indikator etika bisnis, dan model etika dalam bisnis.

\section{B. TEORI ETIKA}

Beberapa teori etika telah dirumuskan oleh banyak ahli. Adapun teori etika tersebut adalah sebagai berikut :

\section{Etika Deontologi}

Istilah 'deontologi' berasal dari kata Yunani deon, yang berarti kewajiban. Karena itu, etika deontologi ini menekankan kewajiban manusia untuk bertindak secara baik. Misanya, suatu 
tindakan bisnis akan dinilai baik oleh etika deontologi bukan karena tindakan itu mendatangkan akibat baik bagi pelakunya, melainkan karena tindakan itu sejalan dengan kewajiban si pelaku. Seperti, memberikan pelayanan yang baik kepada semua konsumen, dan sebagainya. Atas dasar itu, etika deontologi sangat menekankan motivasi, kemauan baik dan watak yang kuat dari pelaku.

'Mengapa perbuatan ini baik dan perbuatan itu harus ditolak sebagai buruk', deontologi menjawab : 'karena perbuatan pertama menjadi kewajiban kita dan karena perbuatan kedua dilarang'. Yang menjadi dasar baik buruknya perbuatan adalah kewajiban. Pendekatan deontologi sudah diterima dalam konteks agama, sekarang merupakan juga salah satu teori etika yang terpenting.

Ada tiga prinsip yg harus dipenuhi :

A. Supaya tindakan punya nilai moral, tindakan ini harus dijalankan berdasarkan kewajiban.

B. Nilai moral dari tindakan ini tidak tergantung pada tercapainya tujuan dari tindakan itu melainkan tergantung pada kemauan baik yang mendorong seseorang untuk melakukan tindakan itu, berarti kalaupun tujuan tidak tercapai, tindakan itu sudah dinilai baik.

C. Sebagai konsekuensi dari kedua prinsip ini, kewajiban adalah hal yang niscaya dari tindakan yang dilakukan berdasarkan sikap hormat pada hukum moral universal. 
Bagi Kant, Hukum Moral ini dianggapnya sbg perintah tak bersyarat (imperatif kategoris), yang berarti hukum moral ini berlaku bagi semua orang pada segala situasi dan tempat.

Perintah Bersyarat adalah perintah yang dilaksanakan kalau orang menghendaki akibatnya, atau kalau akibat dari tindakan itu merupakan hal yang diinginkan dan dikehendaki oleh orang tersebut. Perintah Tak Bersyarat adalah perintah yang dilaksanakan begitu saja tanpa syarat apapun, yaitu tanpa mengharapkan akibatnya, atau tanpa mempedulikan apakah akibatnya tercapai dan berguna bagi orang tersebut atau tidak.

Contoh : Kewajiban seseorang yang memiliki dan mempercayai agamanya, maka orang tersebut harus beribadah, menjalankan perintah dan menjauhi larangan-Nya.

\section{Etika Teleologi}

Etika Teleologi, dari kata Yunani, telos = tujuan, yaitu mengukur baik buruknya suatu tindakan berdasarkan tujuan yang mau dicapai dengan tindakan itu, atau berdasarkan akibat yang ditimbulkan oleh tindakan itu.

Misalnya, mencuri bagi teleologi tidak dinilai baik atau buruk berdasarkan tindakan, melainkan oleh tujuan dan akibat dari tindakan itu. Kalau tujuannya baik, maka tindakan itu dinilai baik. Seperti, seorang anak kecil yang mencuri demi biaya pengobatan ibunya yang sedang sakit. Atas dasar ini, dapat dikatakan bahwa etika teleologi lebih situasional, karena tujuan 
dan akibat suatu tindakan bisa sangat tergantung pada situasi khusus tertentu.

Contoh: Setiap hari saya berolahraga agar sehat dan memiliki tubuh yang bugar sesuai dengan keinginan saya.

Dua aliran etika teleologi :

a. Egoisme Etis

Inti pandangan egoisme adalah bahwa tindakan dari setiap orang pada dasarnya bertujuan untuk mengejar pribadi dan memajukan dirinya sendiri. Satu-satunya tujuan tindakan moral setiap orang adalah mengejar kepentingan pribadi dan memajukan dirinya. Egoisme ini baru menjadi persoalan serius ketika ia cenderung menjadi hedonistis, yaitu ketika kebahagiaan dan kepentingan pribadi diterjemahkan semata-mata sebagai kenikmatan fisik yg bersifat vulgar.

b. Utilitarianisme

Berasal dari bahasa latin utilis yang berarti "bermanfaat". Menurut teori ini suatu perbuatan adalah baik jika membawa manfaat, tapi manfaat itu harus menyangkut bukan saja satu dua orang melainkan masyarakat sebagai keseluruhan.

Dalam rangka pemikiran utilitarianisme, kriteria untuk menentukan baik buruknya suatu perbuatan adalah "the greatest happiness of the greatest number", kebahagiaan terbesar dari jumlah orang yang terbesar. Utilitarianisme, teori ini cocok sekali dengan pemikiran ekonomis, karena cukup dekat dengan CostBenefit Analysis. Manfaat yang dimaksudkan utilitarianisme bisa 
dihitung sama seperti kita menghitung untung dan rugi atau kredit dan debet dalam konteks bisnis.

Utilitarianisme, dibedakan menjadi dua macam :

a. Utilitarianisme Perbuatan (Act Utilitarianism)

b. Utilitarianisme Aturan (Rule Utilitarianism)

\section{Teori Hak}

Dalam pemikiran moral dewasa ini barangkali teori hak ini adalah pendekatan yang paling banyak dipakai untuk mengevaluasi baik buruknya suatu perbuatan atau perilaku. Teori Hak merupakan suatu aspek dari teori deontologi, karena berkaitan dengan kewajiban. Hak dan kewajiban bagaikan dua sisi uang logam yang sama. Hak didasarkan atas martabat manusia dan martabat semua manusia itu sama. Karena itu hak sangat cocok dengan suasana pemikiran demokratis.

Contoh : asisten rumah tangga yang mempunyai hak untuk mendapatkan gaji bulanannya setelah ia melakukan kewajibannya mengurus rumah dan sebagainya.

\section{Teori Keutamaan (Virtue)}

Memandang sikap atau akhlak seseorang. Tidak ditanyakan apakah suatu perbuatan tertentu adil, atau jujur, atau murah hati dan sebagainya. Keutamaan bisa didefinisikan sebagai berikut : disposisi watak yang telah diperoleh seseorang dan memungkinkan dia untuk bertingkah laku baik secara moral. Contoh keutamaan : 

a. Kebijaksanaan
b. Keadilan
c. Suka bekerja keras
d. Hidup yang baik

Keutamaan-keutamaan yang dimilliki manajer dan karyawan sejauh mereka mewakili perusahaan, adalah : Keramahan, Loyalitas, Kehormatan dan Rasa malu. Keramahan merupakan inti kehidupan bisnis, keramahan itu hakiki untuk setiap hubungan antar manusia, hubungan bisnis tidak terkecuali. Loyalitas berarti bahwa karyawan tidak bekerja semata-mata untuk mendapat gaji, tetapi mempunyai juga komitmen yang tulus dengan perusahaan. Kehormatan adalah keutamaan yang membuat karyawan menjadi peka terhadap suka dan duka serta sukses dan kegagalan perusahaan. Rasa malu membuat karyawan solider dengan kesalahan perusahaan.

Contoh :

a. Kebijaksanaan : seorang pemimpin yang memiliki sifat bijaksana dalam segala urusan.

b. Keadilan : mampu bersifat adil dalam menentukan pilihan.

c. Suka bekerja keras : mau terus berjuang dalam bekerja, sehingga pada akhirnya dapat menikmati hasil jerih payahnya yang baik.

d. Hidup yang baik : tidak pernah melakukan hal-hal yang dapat merugikan sekitarnya, dapat menikmati hidup dengan tenang, nyaman dan damai. 


\section{INDIKATOR ETIKA BISNIS}

Implementasi etika dalam penyelenggaraan bisnis mengikat setiap personal menurut bidang tugas yang diembannya. Dengan kata lain mengikat manejer, pimpinan unit kerja, dan kelembagaan perusahaan. Semua anggota organisasi atau perusahaan sesuai dengan tugas pokok dan fungsi harus menjabarkan dan melaksanakan etika bisnis secara konsekuen dan penuh tanggung jawab. Dalam pandangan sempit, suatu perusahaan dianggap telah melaksanakan etika bisnis bila mana perusahaan yang bersangkutan telah melaksanakan tanggung jawab sosialnya. Dari berbagai pandangan tentang etika bisnis, beberapa indicator yang dapat dipakai untuk menyatakan apakah seseorang atau perusahaan telah melaksanakan etika bisnis dalam kegiatan usahanya antara lain:

1. Indicator etika bisnis menurut ekonomi adalah apabila perusahaan atau pebisnis telah melakukan pengelolaan sumber daya bisnis dan sumber daya alam secara efisien tanpa merugikan masyarakat lain.

2. Indicator etika bisnis menurut peraturan khusus yang berlaku. Berdasarkan indicator ini seseorang pelaku bisnis dikatakan beretika dalam bisnisnya apabila masing-masing pelaku bisnis memenuhi aturan-aturan khusus yang telah disepakati sebelumnya. 
3. Indicator etika bisnis menurut hokum. Berdasarkan indicator hukum seseorang atau suatu perusahaan dikatakan telah melaksanakan etika bisnis apabila seorang pelaku bisnis telah mematuhi segala norma hokum yang berlaku dalam menjalankan kegigiatan bisnisnya.

4. Indicator etika berdasarkan ajaran agama. Pelaku bisnis dianggap beretika apabila dalam melaksanakan bisnisnya senantiasa merujuk kepada nilai-nilai agama yang dianutnya.

5. Indicator etika berdasrkan nilai budaya. Setiap pelaku bisnis baik secara individu maupun perusahaan telah menyelenggarakan kegiatan bisnisnya dengan mengakomodsi nilai-nilai budaya dan adat istiadat yang ada di sekitar operasi suatu perusahaan daerah dan suatu bangsa.

6. Indicator etika bisnis menurut masing-masing individuadalah apabila masing-masing pelaku bisnis bertindak jujur dan tidak mengkorbankan integritas pribadinya.

\section{F. MODEL ETIKA DALAM BISNIS}

Carroll dan Buchollz (2005) dalam Rudito dan Famiola (2007:49) membagi tiga tingkatan manajemen dilihat dari cara para pelaku bisnis dalam menerapkan etika dalam bisnisnya.

1. Immoral Manajemen

Immoral manajemen merupakan tingkatan terendah dari model manajemen dalam menerapkan prinsip-prinsip etika bisnis. Manajer yang memiliki manajemen tipe ini pada 
umumnya sama sekali tidak mengindahkan apa yang dimaksud dengan moralitas, baik dalam internal organisasinya maupun bagaimana dia menjalankan aktivitas bisnisnya. Para pelaku bisnis yang tergolong pada tipe ini, biasanya memanfaatkan kelemahan-kelemahan dalam komunitas untuk kepentingan dan keuntungan diri sendiri, baik secara individu atau kelompok mereka. Kelompok manajemen ini selalu menghindari diri dari yang disebut etika. Bahkan hukum dianggap sebagai batu sandungan dalam menjalankan bisnisnya.

\section{Amoral Manajemen}

Tingkatan kedua dalam aplikasi etika dan moralitas dalam manajemen adalah amoral manajemen. Ada dua jenis lain manajemen tipe amoral ini, yaitu :

Pertama, manajer yang tidak sengaja berbuat amoral (unintentional amoral manager). Tipe ini adalah para manajer yang dianggap kurang peka, bahwa dalam segala keputusan bisnis yang diperbuat sebenarnya langsung atau tidak langsung akan memberikan efek pada pihak lain. Oleh karena itu, mereka akan menjalankan bisnisnya tanpa memikirkan apakah aktivitas bisnisnya sudah memiliki dimensi etika atau belum. Manajer tipe ini mungkin saja punya niat baik, namun mereka tidak bisa melihat bahwa keputusan dan aktivitas bisnis mereka apakah merugikan pihak lain atau tidak. Tipikal manajer seperti 
ini biasanya lebih berorientasi hanya pada hukum yang berlaku, dan menjadikan hukum sebagai pedoman dalam beraktivitas.

Kedua, tipe manajer yang sengaja berbuat amoral. Manajemen dengan pola ini sebenarnya memahami ada aturan dan etika yang harus dijalankan, namun terkadang secara sengaja melanggar etika tersebut berdasarkan pertimbanganpertimbangan bisnis mereka, misalnya ingin melakukan efisiensi dan lain-lain. Namun manajer tipe ini terkadang berpandangan bahwa etika hanya berlaku bagi kehidupan pribadi kita, tidak untuk bisnis. Mereka percaya bahwa aktivitas bisnis berada di luar dari pertimbangan-pertimbangan etika dan moralitas.

3. Moral Manajemen

Tingkatan tertinggi dari penerapan nilai-nilai etika atau moralitas dalam bisnis adalah moral manajemen. Dalam moral manajemen, nilai-nilai etika dan moralitas diletakkan pada level standar tertinggi dari segala bentuk perilaku dan aktivitas bisnisnya. Manajer yang termasuk dalam tipe ini hanya menerima dan mematuhi aturan-aturan yang berlaku namun juga terbiasa meletakkan prinsip-prinsip etika dalam kepemimpinannya. Seorang manajer yang termasuk dalam tipe ini menginginkan keuntungan dalam bisnisnya, tapi hanya jika bisnis yang dijalankannya secara legal dan juga tidak melanggar etika yang ada dalam komunitas, seperti keadilan, kejujuran, dan semangat untuk mematuhi hukum yang berlaku. Hukum 
bagi mereka dilihat sebagai minimum etika yang harus mereka patuhi, sehingga aktivitas dan tujuan bisnisnya akan diarahkan untuk melebihi dari apa yang disebut sebagai tuntutan hukum. Manajer yang bermoral selalu melihat dan menggunakan prinsip-prinsip etika seperti, keadilan, kebenaran, dan aturanaturan emas (golden rule) sebagai pedoman dalam segala keputusan bisnis yang diambilnya.

\section{DAFTAR PUSTAKA}

Rudito, Bambang., dan Melia Famiola. 2007. Etika Bisnis dan Tanggung Jawab Sosial Perusahaan di Indonesia. Rekayasa Sains.

https://www.academia.edu/8390883/TEORI-TEORI_ETIKA_BISNIS

http://annie-ocktaviani.blogspot.com/2010/11/teori-teori-etikabisnis.html

http://r4hm190.wordpress.com/2011/10/11/pengertian-contohdari-etika-teleologi-deontologi-teori-hak-teori-keutamaan/

http://bembyagus.blogspot.com/2012/04/teori-teori-etika-bisnisetika.html

http://caeciliaajah.wordpress.com/2012/11/07/prinsip-etikabisnis/

http://yuumenulis.wordpress.com/2012/11/07/teori-etika-etikabisnis/

http://rangga-myteritory.blogspot.com/2012/12/teori-etikabisnis-kata-etika-itu.html 
http://nengmahmudah14.blogspot.co.id/2016/03/teori-etikadalam-bisnis.html 


\section{BAB III}

\section{ETIKA BISNIS DAN BUDAYA}

\section{TUJUAN INSTRUKSIONAL}

Dengan membaca bab ini, mahasiswa diharapkan untuk mampu :

1. Memahami Pengertian Budaya Organisasi

2. Menjelaskan Hubungan antara Etika dengan Kebudayaan

3. Menjelaskan Kendala Dalam Mewujudkan Kinerja Bisnis Etis

4. Memahami Manfaat Tercapainya Tujuan Etika Bisnis Bagi Perusahaan

5. Menjelaskan Pro Dan Kontra Etika Dalam Bisnis

\section{A. PENDAHULUAN}

Perkembangan etika bisnis suatu perusahaan tidak lepas dari budaya yang ada di perusahaan tersebut. Karena bagaimanapun budaya perusahaan akan membentuk perilaku keseharian orang-orang yang ada di perusahaan tersebut. Perusahaan yang memberlakukan budaya disiplin kerja dengan reward dan punishment akan membentuk karyawan yang disiplin sesuai dengan yang diberlakukan oleh perusahaan. Pada bab ini akan dijelaskan tentang pengertian budaya organisasi, hubungan etika dengan budaya, kendala dalam mewujudkan kinerja bisnis etis, manfaat tercapainya tujuan etika bisnis bagi perusahaan. 


\section{B. PENGERTIAN BUDAYA ORGANISASI}

Jika orang-orang bergabung dalam sebuah organisasi, mereka membawa nilai- nilai dan kepercayaan yang telah diajarkan kepada mereka.Tetapi sering terjadi, nilai- nilai tersebut tidak cukup membantu individu yang bersangkutan untuk sukses dalam organisasi.Yang bersangkutan perlu belajar bagaimana organisasi tersebut melakukan kegiatannya. Biasanya diberikan training untuk merestrukturisasikan cara berpikir. Mereka diajarkan untuk berpikir dan bertindak seperti yang dikehendaki organisasi.

Budaya organisasi memberikan ketegasan dan mencerminkan spesifikasi suatu organisasi sehingga berbeda dengan organisasi lain. Budaya organisasi melingkupi seluruh pola perilaku anggota organisasi dan menjadi pegangan bagi setiap individu dalam berinteraksi, baik di dalam ruang lingkup internal maupun ketika berinteraksi dengan lingkungan eksternal.

Oleh karena itu menurut Schein, secara komprehensif budaya organisasi didefenisikan sebagai pola asumsi dasar bersama yang dipelajari oleh kelompok dalam suatu organisasi sebagai alat untuk memecahkan masalah terhadap penyesuaian faktor eksternal dan integrasi faktor internal, dan telah terbukti sah, dan oleh karenanya diajarkan kepada para anggota organisasi yang baru sebagai cara yang benar untuk mempersepsikan, memikirkan dan merasakan dalam kaitannya dengan masalahmasalah yang dihadapi. Hal ini cukup bernilai dan, oleh karenanya 
pantas diajarkan kepada para anggota baru sebagai cara yang benar untuk berpersepsi, berpikir, dan berperasaan dalam hubungannya dengan problem-problem tersebut.

Robbins (2002:279) juga menjelaskan bahwa budaya organisasi menyangkut bagaimana para anggota melihat organisasi tersebut, bukan menyangkut apakah para anggota organisasi menyukainya atau tidak, karena para anggota menyerap budaya organisasi berdasarkan dari apa yang mereka lihat atau dengar di dalam organisasi.

Dan anggota organisasi cenderung mempersepsikan sama tentang budaya dalam organisasi tersebut meskipun mereka berasal dari latar belakang yang berbeda ataupun bekerja pada tingkat-tingkat keahlian yang berlainan dalam organisasi tersebut.Sehingga budaya organisasi dapat disimpulkan sebagai nilai-nilai yang menjadi pegangan sumber daya manusia dalam menjalankan kewajibannya dan juga perilakunya di dalam suatu organisasi.

Menurut Schein budaya organisasi memiliki 3 (tiga) tingkat yaitu: (dalam Stonner 1996:183). Artifak (artifact) adalah hal-hal yang ada bersama untuk menentukan budaya dan mengungkapkan apa sebenarnya budaya itu kepada mereka yang memperhatikan budaya. Artifak termasuk produk, jasa dan bahkan pola tingkah laku dari anggota sebuah organisasi. 
Nilai-nilai yang didukung (espoused values) adalah alasan yang diberikan oleh sebuah organisasi untuk mendukung caranya melakukan sesuatu.

Asumsi dasar (basic assumption) adalah keyakinan yang dianggap sudah ada oleh anggota suatu organisasi.Budaya menetapkan caa yang tepat untuk melakukan sesuatu di sebuah organisasim seringkali lewat asumsi yang diucapkan.

Oleh karena itu budaya organisasi birokrasi akan menentukan apa yang boleh dan tidak boleh dilakukan oleh para anggota organisasi; menentukan batas-batas normatif perilaku anggota organisasai; menentukan sifat dan bentuk-bentuk pengendalian dan pengawasan organisasi; menentukan gaya manajerial yang dapat diterima oleh para anggota organisasi; menentukan cara-cara kerja yang tepat, dan sebagainya. Secara spesifik peran penting yang dimainkan oleh budaya organisasi (birokrasi) adalah membantu menciptakan rasa memiliki terhadap organisasi; menciptakan jati diri para anggota organisasi; menciptakan keterikatan emosional antara organisasi dan pekerja yang terlibat didalamnya; membantu menciptakan stabilitas organisasi sebagai sistem sosial; dan menemukan pola pedoman perilaku sebagaihasil dari norma-norma yang terbentuk dalam keseharian.

Begitu kuatnya pengaruh budaya organisasi (birokrasi) terhadap perilaku para anggota organisasi, maka budaya organisasi (birokrasi) mampu menetapkan tapal batas untuk 
membedakan dengan organisasi (birokrasi) lain; mampu membentuk identitas organisasi dan identitas kepribadian anggota organisasi; mampu mempermudah terciptanya komitmen organisasi daripada komitmen yang bersifat kepentingan individu; mampu meningkatkan kemantapan keterikatan sistem sosial; dan mampu berfungsi sebagai mekanisme pembuatan makna dan simbol-simbol kendali perilaku para anggota organisasi.

\section{HUBUNGAN ETIKA DENGAN BUDAYA}

Meta-ethical cultural relativism merupakan cara pandang secara filosofis yang yang menyatkan bahwa tidak ada kebenaran moral yang absolut, kebenaran harus selalu disesuaikan dengan budaya dimana kita menjalankan kehidupan soSial kita karena setiap komunitas sosial mempunyai cara pandang yang berbedabeda terhadap kebenaran etika.

Etika erat kaitannya dengan moral.Etika atau moral dapat digunakan okeh manusia sebagai wadah untuk mengevaluasi sifat dan perangainya.Etika selalu berhubungan dengan budaya karena merupakan tafsiran atau penilaian terhadap kebudayaan. Etika mempunyai nilai kebenaran yang harus selalu disesuaikan dengan kebudayaan karena sifatnya tidak absolut danl mempunyai standar moral yang berbeda-beda tergantung budaya yang berlaku dimana kita tinggal dan kehidupan social apa yang kita jalani. 
Baik atau buruknya suatu perbuatan itu tergantung budaya yang berlaku.Prinsip moral sebaiknya disesuaikan dengan norma-norma yang berlaku, sehingga suatu hal dikatakan baik apabila sesuai dengan budaya yang berlaku di lingkungan sosial tersebut.Sebagai contoh orang Eskimo beranaggapan bahwa tindakan infantisid (membunuh anak) adalah tindakan yang biasa, sedangkan menurut budaya Amerika dan negara lainnya tindakan ini merupakan suatu tindakan amoral.

Suatu premis yang disebut dengan "Dependency Thesis" mengatakan "All moral principles derive their validity from cultural acceptance". Penyesuaian terhadap kebudayaan ini sebenarnya tidak sepenuhnya harus dipertahankan dan dibutuhkan suatu pengembangan premis yang lebih kokoh.

Etika merupakan suatu pemikiran kritis dan mendasar tentang ajaran-ajaran dan pandangan moral.Etika berasal dari bahasa yunani yaitu kata "ethos" yang berarti suatu kehendak atau kebiasaan baik yang tetap. Manusia yang pertama kali menggunakan kata-kata itu adalah seorang filosof Yunani yang bernama Aristoteles ( 384 - 322 SM ). Menurut Kamus Besar Bahasa Indonesia, etika / moral adalah ajaran tentang baik dan buruk mengenai perbuatan, sikap, kewajiban dan sebagainya. Menurut K. Bertenes, etika adalah nilai-nilai atau norma-norma yang menjadi pegangan bagi seseorang dalam mengatur tingkah lakunya. Etika berkaitan erat dengan berbagai masalah nilai karena etika pada pokoknya membicarakan tentang masalah-masalah 
predikat nilai "susila" dan "tidak susila", "baik" dan "buruk". Kualitas-kualitas ini dinamakan kebajikan yang dilawankan dengan kejahatan yang berarti sifat-sifat yang menunjukkan bahwa orang yang memilikinya dikatakan tidak susila.Sesungguhnya etika lebih banyak bersangkutan dengan prinsip-prinsip dasar pembenaran dalam hubungannya dengan tingkah laku manusia (Katsoff, 1986).

Etika dibagi menjadi 2 kelompok, etika umum dan etika khusus. Etika khusus dibagi menjadi 2 kelompok lagi yaitu etika individual dan etika sosial yang keduanya berkaitan dengan tingkah laku manusia sebagai warga masyarakat.Etika individual membahas kewajiban manusia terhadap diri sendiri dalam kaitannya dengan kedudukan manusia sebagai warga masyarakat. Etika sosial membicarakan tentang kewajiban manusia sebagai anggota masyarakat atau umat manusia.Dalam masalah ini, etika individual tidak dapat dipisahkan dengan etika sosial karena kewajiban terhadap diri sendiri dan sebagai anggota masyarakat atau umat manusia saling berkaitan dan tidak dapat dipisahkan. Etika sosial menyangkut hubungan manusia dengan manusia lain baik secara langsung maupun dalam bentuk kelembagaan (keluarga, masyarakat, dan negara), sikap kritis terhadap pandangan-pandangan dunia, idiologi-idiologi maupun tanggungjawab manusia terhadap lingkungan hidup. Etika sosial berfungsi membuat manusia menjadi sadar akan tanggungjawabnya sebagai manusia dalam kehidupannya sebagai anggota masyarakat. 
Di dunia kita sekarang ini, kesadaran akan etika individual dan etika sosial sangatlah rendah. Contoh nyatanya adalah adanya kelangkaan perspektif etika di kalangan para penguasa politik dan ekonomi yang telah memicu penyalahgunaan kekuasaan (abuse of power) dalam berbagai sudut kehidupan.Parliament of the World's Religion II, tahun 1993, yang diselenggarakan di Chicago, menghasilkan deklarasi yang disebut dengan etika global (global ethic) sebagai penjabaran praktis berupa paradigma etika dan moral untuk diejawantahkan dalam kehidupan empiris.

Lahirnya deklarasi etika global tersebut merupakan realisasi antisipasif dan solutif atas sebuah kekuatan dahsyat bernama globalisasi yang dewasa ini tidak hanya memasuki wilayah kehidupan material seperti ekonomi, budaya, dan politik pada banyak negara di seluruh belahan dunia, tetapi kekuatan tersebut juga merambah wilayah nonmeterial, yaitu etika. Globalisasi sendiri telah banyak menimbulkan dampak positif, tetapi juga dampak negatif, yaitu krisis kemanusiaan.Dunia manusia saat ini sedang dilanda suatu krisis multidimensi global, yang meliputi krisis ekonomi global, krisis ekologi global, dan krisis politik global.Berbagai terpaan krisis tersebut lalu bermuara pada krisis kemanusiaan seperti kemiskinan, kelaparan, pengangguran, kezaliman, kekerasan, penindasan, pengisapan, pembunuhan, dan lain-lain.

Jika ditelusuri secara seksama, kita ketahui krisis kemanusiaan yang ada berpangkal mula dari krisis etika. 
Kelangkaan wawasan dan pengetahuan etika, terutama di kalangan penguasa politik dan ekonomi, mendorong merajalelanya perusakan yang kemudian mengarah pada kerusakan dunia dan segala tatanannya. Dari perspektif etika global, permasalahan yang dihadapi proses peradaban bangsabangsa di dunia belakangan ini, tidak lain adalah masalah etik, yaitu rendahnya kadar apresiasi terhadap etika peradaban. Proses peradaban berkembang sedemikian cepat, terutama pada aspek material yang mengatas namakan kebebasan, kekuatan dan kepercayaan atas diri manusia. Dengan demikian, proses peradaban menempatkan manusia sebagai "pencipta yang memiliki kuasa besar" terhadap hidup dan kehidupannya.Kehidupan manusia kemudian berorientasi pada paradigma "antropo-centris", yaitu berpusat pada diri manusia itu sendiri, sehingga manusia diliputi paham "egoisme kemanusiaan".Egosime kemanusian tersebut, sebagai mana diketahui, menjelma dalam paham, baik yang bersifat individualistis maupun kolektif, sebut saja rasisme, nasionalisme, sekterianisme, atas seksisme (feminisme dan maskulinisme). Semua bentuk egoisme manusia tersebut menghalangi manusia untuk menjadi manusia sejati, manusia berkemanusiaan.

Sebuah paragraf dalam Declaration toward a Global Ethic of the Parliament of the World's Religions yang dikeluarkan di Chicago pada 1993 berbunyi sebagai berikut, "Dalam tradisi etika dan agama umat manusia, kita menemukan perintah: kalian tidak 
boleh mencuri! Atau dalam bahasa positifnya: berdaganglah secara jujur dan adil! Makna dari perintah ini adalah tidak seorang pun berhak dengan cara apa pun merampas atau merebut hak orang lain atau hak kesejahteraan bersama. Begitu juga tidak seorang pun berhak menggunakan apa yang dimilikinya tanpa peduli akan kebutuhan masyarakat dan bumi. Dalam pandangan deklarasi etika global, tidak mungkin ada suatu tatanan dunia baru tanpa tatanan etika global.Etika global, mengacu pada suatu permufakatan mendasar tentang nilai-nilai mengikat, ukuranukuran pasti, dan sikap-sikap pribadi yang harus dimiliki setiap manusia, khususnya manusia beragama.

Pemecahan problematika sosial, ekonomi, politik dan lingkungan hidup mungkin dilakukan dengan proses pembangunan yang berkesinambungan lewat perencanaan ekonomi dan politik serta pembelakuan hukum dan undang-undang. Namun, semua itu belum cukup tanpa perubahan "orientasi batin" (inner orientation) dan sikap mental yang berkualitas dari masyarakat.Masyarakat membutuhkan reformasi sosial dan ekologis, tapi dalam waktu bersamaan mereka juga membutuhkan pembaruan spiritual. Untuk benar-benar berperilaku manusiawi berarti :

Kita harus menggunakan kekuasaan ekonomi dan politik untuk melayani kemanusiaan, bukan menyalahgunakannya dalam persaingan merebut dominasi yang kejam. Kita harus mengembangkan semangat mengasihi mereka yang menderita, 
khususnya kepada anak-anak, kaum lanjut usia, masyarakat miskin, penderita cacat, dan mereka yang berada dalam kesepian.

Kita harus mengembangkan saling respek dan peduli agar tercapai keseimbangan kepentingan yang layak, bukan cuma memikirkan kekuasaan tanpa batas dan persaingan yang tidak terhindarkan.

Kita harus menghargai nilai-nilai kesederhanaan, bukan keserakahan tanpa terpuaskan akan uang, prestis, dan pemuasan konsumtif. Dalam keserakahan, manusia kehilangan "rohnya", kebebasannya, ketenangan, dan kedamaian diri serta dengan demikian kehilangan apa yang membuatnya manusiawi".

\section{KENDALA DALAM MEWUJUDKAN KINERJA BISNIS ETIS}

Pencapaian tujuan etika bisnis di Indonesia masih berhadapan dengan beberapa masalah dan kendala. Keraf (1993:81-83) menyebut beberapa kendala tersebut yaitu:

1. Standar moral para pelaku bisnis pada umumnya masih lemah.

Banyak di antara pelaku bisnis yang lebih suka menempuh jalan pintas, bahkan menghalalkan segala cara untuk memperoleh keuntungan dengan mengabaikan etika bisnis, seperti memalsukan campuran, timbangan, ukuran, menjual barang yang kadaluwarsa, dan memanipulasi laporan keuangan.

2. Banyak perusahaan yang mengalami konflik kepentingan. 
Konflik kepentingan ini muncul karena adanya ketidaksesuaian antara nilai pribadi yang dianutnya atau antara peraturan yang berlaku dengan tujuan yang hendak dicapainya, atau konflik antara nilai pribadi yang dianutnya dengan praktik bisnis yang dilakukan oleh sebagian besar perusahaan lainnya, atau antara kepentingan perusahaan dengan kepentingan masyarakat. Orang-orang yang kurang teguh standar moralnya bisa jadi akan gagal karena mereka mengejar tujuan dengan mengabaikan peraturan.

3. Situasi politik dan ekonomi yang belum stabil.

Hal ini diperkeruh oleh banyaknya sandiwara politik yang dimainkan oleh para elit politik, yang di satu sisi membingungkan masyarakat luas dan di sisi lainnya memberi kesempatan bagi pihak yang mencari dukungan elit politik guna keberhasilan usaha bisnisnya.Situasi ekonomi yang buruk tidak jarang menimbulkan spekulasi untuk memanfaatkan peluang guna memperoleh keuntungan tanpa menghiraukan akibatnya.

4. Lemahnya penegakan hukum.

Banyak orang yang sudah divonis bersalah di pengadilan bisa bebas berkeliaran dan tetap memangku jabatannya di pemerintahan.Kondisi ini mempersulit upaya untuk memotivasi pelaku bisnis menegakkan norma-norma etika.

5. Belum ada organisasi profesi bisnis dan manajemen untuk menegakkan kode etik bisnis dan manajemen. 
Organisasi seperti KADIN beserta asosiasi perusahaan di bawahnya belum secara khusus menangani penyusunan dan penegakkan kode etik bisnis dan manajemen.

\section{E. MANFAAT TERCAPAINYA TUJUAN ETIKA BISNIS BAGI PERUSAHAAN}

Etika bisnis bagi perusahaan ini,menyangkut kebijakan etis perusahaan berhubungan dengan kesulitan yang bisa timbul (mungkin pernah timbul dimasa lalu), seperti konflik kepentingan, hubungan dengan pesaing dan pemasok, menerima hadiah,sumbangan dan sebagainya. Latar belakang pembuatan etika bisnis adalah sebagai cara ampuh untuk melembagakan etika dalam struktur dan kegiatan perusahaan. Bila Perusahaan memiliki etika sendiri,mempunyai beberapa kelebihan dibandingkan dengan perusahaan yang tidak memilikinya. Sementara itu, manfaat etika bisnis bagi perusahaan adalah :

1. Dapat meningkatkan kredibilitas suatu perusahaan, karena etika telah dijadikan sebagai corporate culture. Hal ini terutama penting bagi perusahaan besar yang karyawannya tidak semuanya saling mengenal satu sama lainnya. Dengan adanya etika bisnis, secara intern semua karyawan terikat dengan standard etis yang sama, sehingga akan mefigambil kebijakan/keputusan yang sama terhadap kasus sejenis yang timbul. 
2. Dapat membantu menghilangkan grey area (kawasan kelabu) dibidang etika. (penerimaan komisi, penggunaan tenaga kerja anak, kewajiban perusahaan dalam melindungi lingkungan hidup).

3. Menjelaskan bagaimana perusahaan menilai tanggung jawab sosialnya.

4. Menyediakan bagi perusahaan dan dunia bisnis pada umumnya, kemungkinan untuk mengatur diri sendiri (self regulation).

5. Bagi perusahaan yang telah go publik dapat memperoleh manfaat berupa meningkatnya kepercayaan para investor. Selain itu karena adanya kenaikan harga saham, maka dapat menarik minat para investor untuk membeli saham perusahaan tersebut.

6. Dapat meningkatkan daya saing (competitive advantage) perusahaan.

7. Membangun corporate image / citra positif, serta dalam jangka panjang dapat menjaga kelangsungan hidup perusahaan (sustainable company).

Etika bisnis perusahaan memiliki peran yang sangat penting, yaitu untuk membentuk suatu perusahaan yang kokoh dan memiliki dsaya saing yang tinggi serta mempunyai kemampuan menciptakan nilai yang tinggi,diperlukan suatu landasan yang kokoh. Biasanya dimulai dari perencanaan strategis, organisasi yang baik, system prosedur yang transparan didukung oleh budaya 
perusahaan yang handal serta etika perusahaan yang dilaksanakan secara konsisten dan konsekuen.

Karena itu, tindakan perusahaan berasal dari pilihan dan tindakan individu manusia, indivdu-individulah yang harus dipandang sebagai penjaga utama kewajiban moral dan tanggung jawab moral : individu manusia bertanggung jawab atas apa yang dilakukan perusahaan karena tindakan perusahaan secara keseluruhan mengalir dari pilihan dan perilaku mereka. Jika perusahaan bertindak keliru, kekeliruan itu disebabkan oleh pilihan tindakan yang dilakukan oleh individu dalam perusahaan itu, jika perusahaan bertindak secara moral, hal itu disebabkan oleh pilihan individu dalam perusahaan bertindak secara bermoral.Etika bisnis mempunyai prinsip dalam kaitan ini berhubungan dengan berbagai upaya untuk menggabungkan berbagai nilai-nilai dasar (basic values) dalam perusahaan, agar berbagai aktivitas yang dilaksanakan dapat mencapai tujuan.

Secara lebih jelas, mekanismenya berjalan sebagai berikut."Memaksimumkan kesejahteraan si pemilik dalam jangka panjang", berhubungan dengan dimensi waktu yang relatif panjang serta menyangkut sustainability. Hal ini membutuhkan adanya "kepercayaan" atau "saling mempercayai" (trust) dari berbagai pihak yang berhubungan dengan perusahaan (stakeholders). Kalimat "kesejahteraan pemilik" merupakan derivasi dan perwujudan dari "hak kepemilikan" (ownership) yang 
muncul dari adanya penghargaan (respect) terhadap "kepemilikan pribadi" (property rights).

Haruslah diyakini bahwa pada dasarnya praktik etika bisnis akan selalu menguntungkan perusahaan baik untuk jangka panjang maupun jangka menengah karena :

1. Mampu mengurangi biaya akibat dicegahnya kemungkinan terjadinya friksi, baik intern perusahaan maupun dengan eksternal.

2. Mampu meningkatkan motivasi pekerja.

3. Melindungi prinsip kebebasan berniaga.

4. Mampu meningkatkan keunggulan bersaing.

Tidak bisa dipungkiri, tindakan yang tidak etis yang dilakukan oleh perusahaan akan memancing tindakan balasan dari konsumen dan masyarakat dan akan sangat kontra produktif, misalnya melalui gerakan pemboikotan, larangan beredar, larangan beroperasi dan lain sebagainya. Hal ini akan dapat menurunkan nilai penjualan maupun nilai perusahaan. Sedangkan perusahaan yang menjunjung tinggi nilai-nilai etika bisnis, pada umumnya termasuk perusahaan yang memiliki peringkat kepuasan bekerja yang tinggi pula, terutama apabila perusahaan tidak mentolerir tindakan yang tidak etis, misalnya diskriminasi dalam sistem remunerasi atau jenjang karier.Perlu dipahami, karyawan yang berkualitas adalah aset yang paling berharga bagi perusahaan.Oleh karena itu, perusahaan harus semaksimal mungkin harus mempertahankan karyawannya. Untuk 
memudahkan penerapan etika perusahaan dalam kegiatan seharihari maka nilai-nilai yang terkandung dalam etika bisnis harus dituangkan kedalam manajemen korporasi yakni dengan cara :

1. Menuangkan etika bisnis dalam suatu kode etik (code of conduct)

2. Memperkuat sistem pengawasan

3. Menyelenggarakan pelatihan (training) untuk karyawan secara terus menerus.

\section{DAFTAR PUSTAKA}

A.F. Stoner James, dkk. 1996. Manajemen. Edisi Indonesia. Penerbit PT. Prenhallindo. Jakarta

http://ryusaki69.wordpress.com/2010/05/20/budaya-organisasi/

https://www.academia.edu/28991970/MAKLAH ETIKA DAN BUD AYA ORGANISASI.docX

Keraf, A. Sonny. 1995. Etika Bisnis : Membangun Etika Bisnis Sebagai Profesi Luhur. Penerbit Kanisius. Yogyakarta

Robbins, Stephen.P. 2002. Prinsip-Prinsip Perilaku Organisasi. Penerbit Erlangga. Jakarta. 


\section{BAB IV}

\section{ETIKA BISNIS DAN CORPORATE SOCIAL RESPONSIBILITY}

\section{TUJUAN INSTRUKSIONAL}

Dengan membaca bab ini, mahasiswa diharapkan untuk mampu :

1. Memahami Tentang Corporate Social Resposibility (CSR)

2. Menjelaskan Hubungan Corporate Social Responsibility (CSR) dengan Bisnis

3. Menjelaskan Prinsip - Prinsip yang Harus Dipegang dalam Melaksanakan Corporate Social Responsibility (CSR)

4. Menjelaskan Indikator Keberhasilan Corporate Social Responsibility (CSR)

5. Menjelaskan Hubungan Etika Bisnis dengan CSR

6. Menjelaskan Contoh Kasus Etika Bisnis Dan Tanggung Jawab Sosial

\section{A. PENDAHULUAN}

Etika bisnis dalam kondisi yang sempit atau yang bersifat lokal akan berkaitan dengan bina lingkungan. Istilah ini (bina lingkungan) sangat akrab pada masa era orde baru yang lalu. Maksud dari istilah tersebut bahwa perusahaan harus membina lingkungan yang ada di sekitar perusahaan. Misalnya dalam merekrut karyawan, perusahaan harus lebih mengutamakan masyarakat sekitar. Istilah bina lingkungan tersebut saat ini telah berubah menjadi tanggung jawab social perusahaan atau corporate 
social responsibility atau CSR. Istilah ini memiliki makna yang lebih luas dari bina lingkungan. Pada bab ini akan dibahas tentang Corporate Social Responsibility (CSR), sejarah CSR, prinsip dalam melaksanakan CSR, indicator keberhasilan CSR, dan hubungan etika bisnis dengan CSR.

\section{B. CORPORATE SOCIAL RESPONSIBILITY (CSR)}

Tanggung Jawab Perusahaan (Corporate Social Responsibility) adalah suatu tindakan atau konsep yang dilakukan oleh perusahaan (sesuai kemampuan perusahaan tersebut) sebagai bentuk tanggungjawab mereka terhadap sosial/lingkungan sekitar dimana perusah aan itu berada (Fauzan, 2011). Sementara itu Nuryana (2005) menyatakan bahwa Corporate Social Responsibility (CSR) ialah sebuah pendekatan dimana perusahaan mengintegrasikan kepedulian sosial di dalam operasi bisnis mereka dan dalam interaksi mereka dengan para stakeholder berdasarkan prinsip kemitraan dan kesukarelaan (Nuryana, 2005). CSR juga merupakan bagian yang tidak terpisahkan dari strategi bersaing jagka panjang yang berorientasi pada avokasi pendampingan dan kebijakan publik. CSR (Program Corporate Social Reponsibility) merupakan salah satu kewajiban yang harus dilaksanakan oleh perusahaan sesuai dengan isi pasal 74 Undang-undang Perseroan Terbatas (UUPT) Tahun 2007. Undang-undang ini disyahkan dalam sidang paripurna DPR. 
Dalam pasal 74 ayat 1 diatur mengenai kewajiban Tanggungjawab sosial dan lingkungan bagi perseroan yang menangani bidang atau berkaitan dengan SDA, ayat 2 mengenai perhitungan biaya dan asas kepatutan serta kewajaran, ayat 3 mengenai sanksi, dan ayat 4 mengenai aturan lanjutan. Ketiga, Undang-Undang No.25 Tahun 2007 tentang Penanaman Modal. Pasal 15 (b) menyebutkan bahwa "Setiap penanam modal berkewajiban melaksanakan tanggung jawab sosial perusahaan". Namun UU ini baru mampu menjangkau investor asing dan belum mengatur secara tegas perihal CSR bagi perusahaan nasional. Tentu saja kedua ketentuan undang-undang tersebut diatas membuat fobia sejumlah kalangan terutama pelaku usaha swasta lokal. Apalagi munculnya Pasal 74 UU PT yang terdiri dari 4 ayat itu sempat mengundang polemik. Pro dan kontra terhadap ketentuan tersebut masih tetap berlanjut sampai sekarang. Kalangan pelaku bisnis yang tergabung dalam Kadin dan Asosiasi Pengusaha Indonesia (Apindo) yang sangat keras menentang kehadiran dari pasal tersebut.

Jika ditarik pada berbagai pengertian di atas maka CSR merupakan komitmen perusahaan terhadap kepentingan pada stakeholders dalam arti luas dari sekedar kepentingan perusahaan belaka. Dengan kata lain, meskipun secara moral adalah baik bahwa perusahaan maupun penanam modal mengejar keuntungan, bukan berarti perusahaan ataupun penanam modal 
dibenarkan mencapai keuntungan dengan mengorbankan kepentingan-kepentngan pihak lain yang terkait.

\section{SEJARAH CORPORATE SOCIAL RESPONSIBILITY (CSR)}

Istilah CSR pertama kali menyeruak dalam tulisan Social Responsibility of the Businessman tahun 1953. Konsep yang digagas Howard Rothmann Browen ini menjawab keresahan dunia bisnis. Belakangan CSR segera diadopsi, karena bisa jadi penawar kesan buruk perusahaan yang terlanjur dalam pikiran masyarakat dan lebih dari itu pengusaha di cap sebagai pemburu uang yang tidak peduli pada dampak kemiskinan dan kerusakan lingkungan. Kendati sederhana, istilah CSR amat marketable melalu CSR pengusaha tidak perlu diganggu perasaan bersalah.

CSR merupakan tanggung jawab aktivitas sosial kemasyarakatan yang tidak berorientasi profit. John Elkington dalam buku "Triple Bottom Line" dengan 3P tipe yaitu:

Profit : Mendukung laba perusahaan

People : Meningkatkan kesejahteraan masyarakat

Planet : meningkatkan kualitas lingkungan

Pengertian CSR sangat beragam. Intinya, CSR adalah operasi bisnis yang berkomitmen tidak hanya untuk meningkatkan keuntungan perusahaan secara finansial, tetapi untuk pembangunan sosial-ekonomi kawasan secara holistik, melembaga, dan berkelanjutan. Beberapa nama lain yang memiliki kemiripan dan bahkan sering diidentikkan dengan CSR adalah 
corporate giving, corporate philanthropy, corporate community relations, dan community development. Ditinjau dari motivasinya, keempat nama itu bisa dimaknai sebagai dimensi atau pendekatan CSR. Jika corporate giving bermotif amal atau charity, corporate philanthropy bermotif kemanusiaan dan corporate community relations bernapaskan tebar pesona, community development lebih bernuansa pemberdayaan.

Dalam konteks global, istilah CSR mulai digunakan sejak tahun 1970-an dan semakin populer terutama setelah kehadiran buku Cannibals with Forks: The Triple Bottom Line in 21st Century Business (1998) karya John Elkington. Mengembangkan tiga komponen penting sustainable development, yakni economic growth, environmental protection, dan social equity yang digagas the World Commission on Environment and Development (WCED) dalam Brundtland Report (1987), Elkington mengemas CSR ke dalam tiga fokus: 3P (profit, planet, dan people). Perusahaan yang baik tidak hanya memburu keuntungan ekonomi belaka (profit), tetapi memiliki kepedulian terhadap kelestarian lingkungan (planet) dan kesejahteraan masyarakat (people).

\section{PRINSIP DALAM MELAKSANAKAN CORPORATE SOCIAL RESPONSIBILITY (CSR)}

Prinsip pertama adalah kesinambungan atau sustainability. Ini bukan berarti perusahaan akan terus-menerus memberikan bantuan kepada masyarakat. Tetapi, program yang 
dirancang harus memiliki dampak yang berkelanjutan. CSR berbeda dengan donasi bencana alam yang bersifat tidak terduga dan tidak dapat di prediksi. Itu menjadi aktivitas kedermawanan dan bagus.

Prinsip kedua, CSR merupakan program jangka panjang. Perusahaan mesti menyadari bahwa sebuah bisnis bisa tumbuh karena dukungan atmosfer sosial dari lingkungan di sekitarnya. Karena itu, CSR yang dilakukan adalah wujud pemeliharaan relasi yang baik dengan masyarakat. la bukanlah aktivitas sesaat untuk mendongkrak popularitas atau mengejar profit.

Perinsip ketiga, CSR akan berdampak positif kepada masyarakat, baik secara ekonomi, lingkungan, maupun sosial. Perusahaan yang melakukan CSR mesti peduli dan mempertimbangkan sampai kedampaknya.

Prinsip keempat, dana yang diambil untuk CSR tidak dimasukkan ke dalam cost structure perusahaan sebagaimana budjet untuk marketing yang pada akhirnya akan ditransformasikan ke harga jual produk. "CSR yang benar tidak membebani konsumen.

\section{E. INDIKATOR KEBERHASILAN CORPORATE SOCIAL RESPONSIBILITY (CSR)}

Indikator keberhasilan dapat dilihat dari dua sisi perusahaan dan masyarakat. Dari sisi perusahaan, citranya harus semakin baik di mata masyarakat. Sementara itu, dari sisi 
masyarakat, harus ada peningkatan kualitas hidup. Karenanya, penting bagi perusahaan melakukan evaluasi untuk mengukur keberhasilan program CSR, baik secara kuantitatif maupun kualitatif. Satu hal yang perlu diingat, "Salah satu ukuran penting keberhasilan CSR adalah jika masyarakat yang dibantu bisa mandiri, tidak melulu bergantung pada pertolong orang lain.

Kegiatan CSR akan menjamin keberlanjutan bisnis yang dilakukan. Hal ini disebabkan karena :

1. Menurunnya gangguan social yang sering terjadi akibat pencemaran lingkungan, bahkan dapat menumbuh kembangkan dukungan atau pembelaan masyarakat setempat.

2. Terjaminnya pasokan bahan baku secara berkelanjutan untuk jangka panjang.

3. Tambahan keuntungan dari unit bisnis baru, yang semula merupakan kegiatan CSR yang dirancang oleh korporat.

Adapun 5 pilar yang mencakup kegiatan CSR yaitu:

1. Pengembangan kapasitas SDM di lingkungan internal perusahaan maupun lingkungan masyarakat sekitarnya.

2. Penguatan ekonomi masyarakat sekitar kawasan wilayah kerja perusahaan.

3. Pemeliharaan hubungan relasional antara korporasi dan lingkungan sosialnya yang tidak dikelola dengan baik sering mengundang kerentanan konflik.

4. Perbaikan tata kelola perusahaan yang baik 
5. Pelestarian lingkungan, baik lingkungan fisik, social serta budaya.

Sementara itu, menurut Wibisono (2007) menyatakan bahwa perusahaan akan mendapatkan 10 keuntungan apabila menerapkan program CSR, yaitu :

1. Mempertahankan dan mendongkrak reputasi dan image perusahaan. Perbuatan destruktif pasti akan menurunkan reputasi perusahaan, sebaliknya kontribusi positif pasti akan mendongkrak image dan reputasi positif perusahaan. Image / citra yang positif ini penting untuk menunjang keberhasilan perusahaan.

2. Layak Mendapatkan sosial licence to operate. Masyarakat sekitar adalah komunitas utama perusahaan. Ketika mereka mendapatkan keuntungan dari perusahaan, maka dengan sendirinya mereka akan merasa memiliki perusahaan. Sehingga imbalan yang diberika kepada perusahaan adalah keleluasaan untuk menjalankan roda bisnisnya di kawasan tersebut.

3. Mereduksi Resiko Bisnis Perusahaan. Mengelola resiko di tengah kompleksnya permasalahan perusahaan merupakan hal yang esensial untuk suksesnya usaha. Disharmoni dengan stakeholders akan menganggu kelancaran bisnis perusahaan. Bila sudah terjadi permasalahan, maka biaya untuk recovery akan jauh lebih berlipat bila dibandingkan dengan anggaran untuk melakukan program Corporate Social Responsibility. Oleh karena itu, pelaksanaan CSR sebagai langkah preventif 
untuk mencegah memburuknya hubungan dengan stakeholders perlu mendapat perhatian. (4) Melebarkan Akses Sumber Daya. Track records yang baik dalam pengelolaan CSR merupakan keunggulan bersaing bagi perusahaan yang dapat membantu memuluskan jalan menuju sumber daya yang diperlukan perusahaan. (5) Membentangkan Akses Menuju Market. Investasi yang ditanamkan untuk program CSR ini dapat menjadi tiket bagi perusahaan menuju peluang yang lebih besar. Termasuk di dalamnya memupuk loyalitas konsumen dan menembus pangsa pasar baru. (6) Mereduksi Biaya. Banyak contoh penghematan biaya yang dapat dilakukan

Berikut ini adalah manfaat CSR bagi masyarakat:

1.Meningkatknya kesejahteraan masyarakat sekitar dan kelestarianlingkungan.

2. Adanya beasiswa untuk anak tidak mampu di daerah tersebut.

3. Meningkatnya pemeliharaan fasilitas umum.

4. Adanya pembangunan desa/fasilitas masyarakat yang bersifat sosial dan berguna untuk masyarakat banyak khususnya masyarakat yang berada di sekitar perusahaan tersebut berada.

Berikut ini adalah manfaat CSR bagi perusahaan:

1. Meningkatkan citra perusahaan.

2. Mengembangkan kerja sama dengan perusahaan lain.

3. Memperkuat brand merk perusahaan dimata masyarakat. 
4. Melebarkan Akses Sumber Daya. Track records yang baik dalam pengelolaan CSR merupakan keunggulan bersaing bagi perusahaan yang dapat membantu memuluskan jalan menuju sumber daya yang diperlukan perusahaan.

5. Membentangkan Akses Menuju Market. Investasi yang ditanamkan untuk program CSR ini dapat menjadi tiket bagi perusahaan menuju peluang yang lebih besar. Termasuk di dalamnya memupuk loyalitas konsumen dan menembus pangsa pasar baru.

6. Mereduksi Biaya. Banyak contoh penghematan biaya yang dapat dilakukan dengan melakukan CSR. Misalnya: dengan mendaur ulang limbah pabrik ke dalam proses produksi. Selain dapat menghemat biaya produksi, juga membantu agar limbah buangan ini menjadi lebih aman bagi lingkungan.

7. Memperbaiki Hubungan dengan Stakehoder. Implementasi CSR akan membantu menambah frekuensi komunikasi dengan stakeholders, dimana komunikasi ini akan semakin menambah trust stakeholders kepada perusahaan.

8. Memperbaiki Hubungan dengan Regulator. Perusahaan yang melaksanakan CSR umumnya akan meringankan beban pemerintah sebagai regulator yang sebenarnya bertanggung jawab terhadap kesejahteraan lingkungan dan masyarakat.

9. Meningkatkan semangat dan produktivitas karyawan. Image perusahaan yang baik di mata stakeholders dan kontribusi positif yang diberikan perusahaan kepada masyarakat serta 
lingkungan, akan menimbulkan kebanggan tersendiri bagi karyawan yang bekerja dalam perusahaan mereka sehingga meningkatkan motivasi kerja mereka.

10.Peluang Mendapatkan Penghargaan. Banyaknya penghargaan atau reward yang diberikan kepada pelaku CSR sekarang, akan menambah kans bagi perusahaan untuk mendapatkan award.

\section{F. HUBUNGAN ETIKA BISNIS DENGAN CORPORATE SOCIAL RESPONSIBILITY}

Apa hubungan antara etika bisnis (bussines ethic) dengan CSR (Corporate Social Responsibility)?. Sebagian orang mungkin menganggap keduanya tidak memiliki hubungan, namun dalam kenyataannya keduanya itu saling berhubungan. Hubungan antara etika bisnis (bussines ethic) dengan CSR (Corporate Social Responsibility) yaitu bisa diibaratkan etika bisnis itu adalah sebagai dasar atau jiwa dari pelaksanaan suatu unit usaha, dan CSR merupakan manifestasinya. Artinya, "Etika bisnis berbicara mengenai nilai, apakah sebuah perusahaan tersebut menganut nilai yang baik atau buruk. Kalau memang memiliki nilai yang baik dalam berbisnis, maka perusahaan tersebut akan menjalankan CSR yang memang menjadi tanggung jawab suatu perusahaan". Etika bisnis itu lebih melekat kepada individu yang melakukan etika bisnis, sedangkan CSR yaitu sebagai kebijakan dari perusahaan tersebut. Dalam menentukan etika bisnis ada beberapa hal yang harus perlu diperhatikan, yaitu sebagai berikut: 


\section{Pengendalian diri}

Artinya setiap dari pelaku bisnis yang terkait harus mampu mengendalikan dirinya mereka masing-masing untuk tidak memperoleh apapun, dari siapapun dalam bentuk apapun. Disamping itu, pelaku bisnis sendiri tidak diperbolehkan mendapat keuntungan dengan cara main curang, tetapi penggunannya juga harus memperhatikan kondisi masyarakat sekitarnya.

2. Pengembangan tanggung jawab sosial (Social Responsibility)

Artinya disini pelaku bisnis itu dituntut agar peduli kepada keadaan masyarakat dimana perusahaan tersebut berada. Maksudnya bukan hanya dengan memberi sumbangan berupa uang tetapi bisa juga dengan memberi perhatian yang lebih kompleks lagi, misalnya dngan memberi bantuan seperti membuka lapangan pekerjaan bagi masyarakat yang ada di sekitar perusahaan tersebut.

3. Menumbuhkan Sikap Saling Percaya

Dalam menjalankan suatu usaha perlu adanya rasa saling percaya, sehingga dapat tercipta suasana yang aman, nyaman, dan damai. Adanya rasa saling percaya antar golongan yang kuat dan golongan yang lemah ini dapat saling menguntungkan bagi kedua belah pihak karena adanya timbal balik yang baik dan berjalan lancar.

Kepedulian kepada masyarakat dapat diartikan sangat luas, namun secara singkat dapat dimengerti sebagai peningkatan partisipasi dan posisi organisasi di dalam sebuah komunitas 
melalui berbagai upaya kemaslahatan bersama bagi organisasi dan komunitas. CSR bukan hanya sekedar kegiatan amal saja, namun CSR itu mengharuskan suatu perusahaan dalam pengambilan keputusannya agar dengan sungguh-sungguh memperhitungkan akibat terhadap seluruh pemangku kepetingan (stakeholder) perusahaan, termasuk lingkungan hidup. Hal ini mengaharuskan untuk perusahaan membuat keseimbangan kepentingan pemegang saham, yang merupakan salah satu pemangku kepentingan internal.

Manfaat etika bisnis dan dan tanggung jawab sosial perusahaan, yaitu sebagai berikut:

1. Perusahaan yang etis dan memiliki tanggung jawab sosial mendapat rasa hormat dari stekholder.

2. Perusahaan yang etis dan memiliki tanggung jawab sosial akan mendapat kepercayaan dari konsumen maupun masyarakat sekitar.

3. Perusahaan yang etis dan memiliki tanggung jawab sosial membantu dalam pembangunan daerah sekitar perusahaan.

4. Perusahaan yang etis dan memiliki tanggung jawab sosial secara tidak langsung membantu dalam promosi perusahaan.

5. Suatu perusahaan yang etis dan memiliki tanggung jawab sosial akan terhindar dari seluruh pengaruh yang merusak berkaitan dengan reputasi.

Perkembangan yang semakin maju menuntut para pebisnis untuk meningkatkan daya saingnya apalagi setelah 
dibebaskannya pasar bebas yang mengakibatkan laju pertumbuhan perekonomian dunia semakin cepat, dan jarak antar negara semakin menghilang karena diberlakukannya sistem ini, tidak hanya itu akibat dari pasar bebas juga membuat perusahaan atau pengusaha yang memilki bisnis harus mampu bersaing dengan para pengusaha asing. Hal itu juga akan mendorong beberapa instansi atau orang untuk menghalalkan segala cara untuk mendapatkan kentungan sehingga bisa merugikan pihak yang lainnya. Dalam hal ini adanya etika bisnis islam dapat mengendalikan penyimpangan itu terjadi sehingga tidak ada pihak yamg merasa dirugikan. Dalam perkembangan bisnis, sekarang apalagi sudah memasuki era globalisasi di mana batas negara bukan halangan lagi untuk mengembangkan bisnis, indonesia sebagai negara berkembang harus mampu meningkatkan kualitas sumber daya manusianya agar mampu menghadapi kompetisi persaingan yang semakin kompetitif. Etika bisnis dan tanggung jawab sosial perusahaan merupakan kunci keberlanjutan perusahaan dalam jangka panjang. Keduanya merupakan dua hal yang sama pentingnya dilakukan oleh perusahaan apapun bisnisnya.

\section{DAFTAR PUSTAKA}

Fauzan. 2011. Corporate Social Responsibility dan Etika Bisnis. (Perspektif Etika Moral Immanuel Kant). Modernisasi. Vol 7 No 2. HIm $115-133$. 
https://www.scribd.com/doc/174000988/Contoh-Kasus-EtikaBisnis-Dan-Tanggung-Jawab-Sosial

http://seputar-mahasiswa.blogspot.co.id/2013/10/pengertian-csrmanfaat-csr-dan_3763.html

https://alliyabenings.wordpress.com/2015/12/06/makalahpengantar-bisnis-corporate-social-responsibility/

https://indonesiana.tempo.co/read/119320/2017/11/15/oktacant ik227/hubungan-etika-bisnis-dengan-csr

Nuryana, Mu'man. 2005. Corporate Social Responsibility Dan Kontribusi bagi Pembangunan Berkelanjutan. Makalah. Disampaikan pada diklat pekerjaan sosial industri. Balai Besar Pendidikan dan Pelatihan Kesejahteraan sosial (BBPPKS), Lembang. Bandung

Wibisono, Yusuf. 2007. Membedah Konsep \& Aplikasi CSR (Corporate Social Responsibility). PT Gramedia. Jakarta. 


\section{BAB V}

\section{ISLAM DAN ETIKA BISNIS}

\section{TUJUAN INSTRUKSIONAL}

Dengan membaca bab ini, mahasiswa diharapkan mampu untuk :

1. Memahami dan Menjelaskan Sumber Islam

2. Menjelaskan Tentang etika bisnis dan tanggung jawab sosial dalam pandangan islam.

3. Penegasan-penegasan dalam Islam sehubungan dengan aturan dalam berbisnis.

\section{A. PENDAHULUAN}

Islam menjelaskan bagaimana mengatur kehidupan manusia dimuka bumi. Hal ini termasuk mengatur dalam urusan berbisnis. Berbisnis berbasiskan konsep Islam telah terjelaskan secara detail dalam pedoman umat Islam. Bab ini kita akan menjelaskan mengenai Islam dan etika bisnis beserta ruang lingkupnya. Dengan memahami secara utuh etika bisnis dalam pandangan islam, maka kita dapat menghindari perbuatan perbuatan bisnis (Bisnis Judi, Khamar, Riba, Monopoli dan sebagainya) oleh yang di larang Allah SWT.

\section{B. SUMBER ISLAM}

Tatanan ekonomi Islam disusun berdasarkan sumber dari Al Qur'an, Al Hadits, Qiyas dan ljma' para Ulama. Al ur'an 
merupakan pedoman hidup umat manusia yang diturun ke dunia melalui perantara malaikat jibril dan diwahyukan Allah SWT kepada Nabi Muhammad SAW. Sehingga redaksinya langsung berasal dari Allah SWT. Sedangkan Al Hadist yakni perkataan, perilaku serta kebiasaan Nabi Muhammad SAW yang menjadi suri tauladan. Oleh sebab itu Al Qur'an dan Al Hadits dijadikan dasar rujukan dalam kehidupan umat muslim di dunia, segala sesuatunya disesuaikan dengan isi kandungan dalam Al Qur'an dan Al Hadits. Sebagai seorang muslim wajib memahami isi Al Qur'an dan mampu menafsirkannya dengan baik. Jika belum mampu dapat bertanya pada ahli tafsir (Fahmi:2013).

\section{ETIKA BISNIS DAN TANGGUNG JAWAB SOSIAL DALAM ISLAM}

Terdapat perbedaan mendasar dalam model ekonomi islam dan ekonomi lainnya. Ekonomi islam memadukan antara ilmu dan etika dimana ekonomi ini tidak memisahkan antara ilmu ilmu yang lain dengan etika. Sistem ekonomi islam memiliki tujuan menciptakan kondisi yang Ibih baik bagi kehidupan umat manusa. Atau dengan cara memahami Al Qur'an dan Al Hadits serta mampu mengimplementasikannya dalam kehidupan sehari-hari. (QS Al Baqarah:30), dengan ditunjuknya manusia sebagai khalifah di bumi maka allah memberikan hak pada manusia untuk memanajemen isi bumi dan mempertanggungjawabkannya.

Seorang muslim harus menyadari bahwa kekayaan yang dia miliki baik berupa harta, tahta, anak, dsb merupakan titipan 
sementara dari allah swt. Oleh karena itu manusia harus mampu mengelolanya dengan sebaik-baiknya agar dapat memberikan manfaat kepada makhluk lainnya. Jangan sampai titipan sementara yang diberikan oleh allah swt menjadikan manusia bersifat hedonisme. Hedonisme yakni sifat yang menjadikan harta sebagai tuhan yang disembah dan hanya mengejar kesenangan duniawi. (QS Al Mukmin:34-40)

Bagi seorang muslim jangan menjadikan harta itu sebagai bagian yang membuatnya sombong diatas muka bumi. Harta itu jadikanlah sebagai sarana guna menunjang terwujudnya tujuan. Dengan adanya iman di dalam dada seorang muslim maka harta itu akan selalu digunakan untuk berbagi kebahagiaan dengan sesama muslim yang lainnya (QS Al- Baqarah:254). Maka nafkahkanlah hartamu pada jalan allah dan ringankanlah beban fakir miskin. Terbangunnya sikap dermawan dalam hati umat islam telah menjadikan umat islam sebagai makhluk yang memperhatikan keadaan sesama dan mendorong manusia untuk bangkit dari kemelaratan dan menyongsong hari depan yang lebih cerah. Sikap ini akhirnya akan melahirkan suatu rasa persatuan dan kesatuan yang kuat. Sebab allah sangat membenci manusia yang bersifat kikir dan suka mengeksploitasi kaum yang lemah demi kepentingan pribadi atau golongan. Sebuah kisah menceritakan bagaimana seorang muslim yang tidak suka membant muslim lainnya akan mendapatkan teguran keras dari Allah SWT. Bagi segolongan orang yang tidak menghiraukan 
seruan ini akan ditarik kembali nikmat yang ia peroleh dan menggantinya dengan berbagai bencana seperti bencana alam, sakit berkepanjangan, kebangkrutan usaha dsb.

Islam menginginkan umatnya hidup dalam kesederhanaan sebagaimana kehidupan rasulullah saw yang jauh kehidupan berfoya-foya (QS Al-A'rof:31). ciri-ciri orang yang hidup dengan konsumsi berlebih-lebihan merupkan ciri masyarakat yang tidak mengenal tuhan. Sifat ini disebut dengan istilah ISRAF (Pemborosan) atau TAFZHIR (Menghambur-hamburkan harta tanpa guna). Tafzhir berarti mempergunakan harta dengan cara yang salah untuk tujuan-tujuan yang terlarang seperti penyuapan dan melanggar hukum. Sedangkan bagi orang yang berlebihan harta namun tetap hidup boros atau tidak mampu mengelola keuangan pribadi maka islam mempunyai cara penyelesaian dalam hukum islam (fiqih), orang semacam ini seharusnya dikenai pembatasan dan bila perlu dilepaskan dan dibebaskan dari tugas untuk mengurus harta miliknya. Dalam pandangan syariah dia seharusnya mencari orang lain yang ditugaskan untuk mengurus hartanya. Ini dimaksudkan agar manusia itu berjaga-jaga karena harta itu tidak selamanya kita miliki dan bila nantinya suatu saat kita membutuhkan untuk keperluan biaya pengobatan, pendidikan, ekspansi usaha kita masih punya simpanan.

Islam memperbolehkan manusia untuk mencari harta sebanyak mungkin diatas bumi allah tapi ingatlah bahwa ada peringatan yang diberikan bagi orang-orang yang lupa kepada 
allah dan berbuat kekacauan diatas muka bumi ini (QS Al Qashas : 77). Setiap manusia yang bekerja harus dijamin hak-haknya dan terbebas dari eksploitasi individu lainnya. Rasulullah saw mengingatkan manusia untuk takut akan kezhaliman karena sesungguhna kezhaliman itu akan menjadi kegelapan pada hari pembalasan. Peringatan seperti ini bertujuan untuk melindungi hak-hak individu dalam kehidupan bemasyarakat tertama di lingkungan kerja.

Islam menganjurkan umatnya untuk berusaha namun harus mematuhi aturan dan peraturan itu tidak boleh dilanggar. Sebab semua itu bertujuan agar manusia tidak menimbulkan kerusakan, perpecahan dan pertumpahan darah di bumi. Kerusakan dan kehancuran yang ditimbulkan bisa terjadi jika mereka terlalu sibuk mengejar materi sehingga lupa dengan ibadah Terutama untuk urusan shalat. Sebab shalat itu tiang agama dan allah swt memberi peringatan keras bagi mereka yang lalai mendirikan shalat dan lebih mengutamakan urusan bisnis. Orang yang mengesampingkan shalat maka dengan sendirinya iman dan ketaatanya akan turun sehingga ini menyebabkan ia lebih memikirkan urusan duniawi yang pada akhirnya akan berwujud pada suatu pemikiran bahwa segala yang ia peroleh disebabkan oleh kerja kerasnya bukan karena pemberian yang diatas (Gustin, 2008).

\section{ISLAM DAN ATURAN BISNIS YANG BERETIKA}


Dalam pandangan islam terdapat bisnis-bisnis yang dilarang dikerjakan sebab bisnis ini lebih besar kerugiannya dibanding manfaatnya seperti bisnis pelacuran, minuman keras atau khamr, kasino atau judi, atau beternak binatang yang diharamkan oleh islam (Fahmi, 2013).

Adapun bahaya berbisnis minuman keras dan judi dijelaskan Allah dalam QS Al Baqarah : 219. Bahaya dari minuman keras adalah merusak kesehatan manusia dan bahaya dari judi membuat manusia tidak suka bekerja keras dan terbiasa dengan pikiran khayalannya untuk mendapatkan uang banyak dalam waktu yang cepat.

Dalam hidup ini khususnya dalam berbisnis sangat menghargai dan menjunjung tinggi nilai-nilai persaudaraan sehingga dalam masyarakat islam berbisnis bukan hanya bertujuan untuk mencari keuntungan. Sehingga nantinya dengan berdagang atau berbisnis akan menambah dan mempererat ikatan ukhuwah islamiyah yang semakin baik.

Islam melarang manusia memanfaatkan ketidaktahuan saudara sesama muslimnya terhadap suatu hal seperti barang. Islam berusaha keras untuk mencegah terjadinya suatu tindakan yang dilakukan dalam penjualan barang yang tidak jelas rupa dan sifatnya yang dapat menimbulkan kerugian bagi orang lain (bai "ul gharar").

Islam juga idak menyukai jika umatnya melakukan riba. Dalam Firman-NYA Allah menghalalkan jual beli dan 
mengharamkan riba. Pada dasarnya sistem ribawi ini mengakibatkan transaksi dan kegiatan ekonomi sektor moneter mengelembungkan berpuluh kali lipat dibandingkan dengan transaksi dalam kegiatan ekonomi sektor rill. Faktanya di lapangan perekonomian sektor rill yang menopang perekonomian suatu negara. Jika dilihat dari beberapa faktor ang menyebabkan terjadinya krisis ekonomi yang melanda dunia sejak awal abad 20 hingga saat ini, semua itu bersumber pada ketidakadilan dan diantaranya dengan diterapkannya sistem ekonomi ribawi (sistem bunga) dalam perekonomian yang mengakibatkan biaya ekonomi tinggi serta mengakibatkan tumbuhnya kegiatan speakulasi di pasar uang dan pasar modal (Fahmi, 2013)..

Islam membedakan riba dalam dua macam yaitu riba nasiah dan riba fadhi. Riba nasiah ialah suatu pembayaran lebih yang disyaratkan oleh orang yang meminjamkan. Riba fadhi ialah penukaran suatu barang dengan barang sejenis, tetapi lebih banyak jumahnya karena orang yang menukarkan mensyaratkan demikian. Berbisnis secara riba sangat dibenci dalam islam, sebab mereka yang melakukan riba memperoleh untung dari kepayahan dan kesusahan orang lain. Mereka melakukannya dengan memberi fasilitas dalam bentuk pinjaman uang kepada yang membutuhkan terutama yang sangat - sangat membutuhkan dengan menetapkan bunga tinggi serta bila telat mengembalikan akan dikenakan bunga tambahan. Perbuatan riba ini membuat tata ekonomi masyarakat menjadi kacau (Muthahhari, 2004). 
Perbuatan lain yang merugikan yakni melakukan tindakan monopoli (hanya ada satu penjual dan banyak pembeli) sehingga membuat mekanisme harga tidak ditentukan oleh pasar tetapi oleh satu pihak saja. Dengan kekuasaan monopoli seseorang dengan bebas mempermainkan harga dan secara otomatis bisa mempermainkan kebutuhan orang banyak. Rasulullah SAW bersabda, "Barang siapa memonopoli makanan selama 40 hari maka hatinya akan menjadi beku dan keras."

Sehingga dalam islam menentang konsep spekulasi dengan melihat celah - celah dimana keuntungan bisa diambil seperti saat terjadi inflasi. Konsep investasi dalam islam dikenal dengan istilah interest less society, sharing risk dan sharing profit and loss. Konsep dalam islam ini menawarkan win - win solution bagi masyarakat sehingga tidak ada yang di rugikan. Bagi seorang muslim juga diwajibkan memunaikan rukun islam yang ke empat yakni zakat. Begitupun bagi sebuah bisnis, jika sudah mencapai hisabnya bisnis wajib mengeluarkan zakat maal. Zakat diatur berdasarkan ketentuan yang berlaku. Zakat dibayarkan pada mereka yang berhak memperolehnya sesuai ketetapan Allah SWT dalam Al Quran (Muthahhari, 2004). 


\section{DAFTAR PUSTAKA}

Al- Quran

Fahmi, Irham . 2013. Etika Bisnis: Teori, Kasus dan Solusi. Bandung: Alfabeta.

Gustin. 2008. "Etika Bisnis Suatu Kajian Nilai Dan Moral Dalam Bisnis" Jurnal Ekonomi Dan Bisnis Vol.3 No.2

Muthahhari, Murthada. 2004. Filsafat Moral Islam. Jakarta: Penerbit Al-Huda 


\section{BAB VI}

\section{ETIKA PROFESI AKUNTAN}

\section{TUJUAN INSTRUKSIONAL}

Dengan membaca bab ini, mahasiswa diharapkan mampu untuk :

1. Memahami Prinsip-Prinsip Etika Profesi Ikatan Aluntan Indonesia

2. Menjelaskan Tentang Prinsip Tanggung Jawab Profesi

3. Menjelaskan Tentang Prinsip Kepentingan Publik

4. Menjelaskan Tentang Prinsip Integritas

5. Menjelaskan Tentang Prinsip Obyektivitas

6. Menjelaskan Tentang Prinsip Kompetensi dan Kehati-Hatian Profesional

7. Menjelaskan Tentang Prinsip Kerahasiaan

8. Menjelaskan Tentang Prinsip Perilaku Profesional

9. Menjelaskan Tentang Standar Teknis

\section{A. PENDAHULUAN}

Dalam menjalankan profesinya, seorang akuntan diatur oleh suatu kode etik akuntan. Kode etik akuntan yaitu norma perilaku yang mengatur hubungan antara akuntan dengan para klien, antara akuntan dengan sejawatnya, dan antara profesi dengan masyarakat. Akuntan publik sebagai pihak yang bebas dan tidak memihak (independen ) dalam melakukan pemeriksaan yang 
objektif atas laporan keuangan dan menyatakan pendapatnya atas kewajaran laporan keuangan, sangat diperlukan jasanya oleh masyarakat pengguna laporan keuangan. Guna meningkatkan kepercayaan pemakai jasa profesi akuntan publik sebagaimana layaknya yang mereka harapkan, maka perlu adanya kode etik akuntan, termasuk kode etik bagi akuntan publik. Dengan adanya kode etik, para akuntan publik dapat menentukan mana perilaku yang pantas (etis) ia lakukan dan mana yang tidak pantas ( tidak etis). Penetapan kode etik oleh Ikatan Akuntan Indonesia (IAI) sebagai satu-satunya organisasi profesi di Indonesia, merupakan upaya dalam rangka penegakan etika, dalam hal ini khususnya bagi akuntan publik.

Ciri pembeda profesi akuntansi adalah kesediaannya menerima tanggung jawab untuk bertindak bagi kepentingan publik. Oleh karena itu, tanggung jawab Akuntan Profesional tidak hanya terbatas pada kepentingan klien atau pemberi kerja. Dalam bertindak bagi kepentingan publik, Akuntan Profesional memerhatikan dan mematuhi ketentuan Kode Etik ini. Jika Akuntan Profesional dilarang oleh hukum atau peraturan untuk mematuhi bagian tertentu dari Kode Etik ini, Akuntan Profesional tetap mematuhi bagian lain dari Kode Etik ini.

Kode Etik ini terdiri atas tiga bagian, bagian A menetapkan prinsip dasar etika profesional bagi Akuntan Profesional dan memberikan kerangka konseptual yang akan diterapkan Akuntan Profesional dalam: (a) Mengidentifikasi ancaman terhadap 
kepatuhan pada prinsip dasar etika; (b) Mengevaluasi signifikansi ancaman tersebut; dan (c) Menerapkan perlindungan yang tepat untuk menghilangkan atau mengurangi ancaman tersebut sampai ke tingkat yang dapat diterima. Perlindungan diperlukan ketika Akuntan Profesional menentukan bahwa ancaman itu tidak berada pada tingkat yang mana pihak ketiga yang rasional dan memiliki informasi yang cukup, berdasarkan semua fakta dan keadaan tertentu yang tersedia bagi Akuntan Profesional pada saat itu, akan menyimpulkan bahwa kepatuhan pada prinsip dasar etika tidak berkurang. Akuntan Profesional menggunakan pertimbangan profesionalnya dalam menerapkan kerangka konseptual ini.

Berkembangnya profesi akuntan publik, telah banyak diakui oleh berbagai kalangan masyarakat. Sedikit tidaknya masyarakat dunia usaha telah menggantungkan kebutuhan bisnisnya dengan jasa akuntan publik. Seiring dengan perkembangan tersebut, muncul pula suatu fenomena baru di tengah kehidupan bisnis masyarakat kita akhir-akhir ini. Meskipun IAI sudah menetapkan kode etik bagi akuntan termasuk akuntan publik, tetapi masih tetap ada pelanggaranpelanggaran etika. Adanya pelanggaranpelanggaran etika ini tentu saja menimbulkan krisis kepercayaan terhadap profesi akuntan publik itu sendiri. Ini merupakan tantangan bagi akuntan publik pada masa yang akan datang untuk tetap mempertahankan citra profesinya di mata masyrakat. Oleh karena itu sudah sewajarnya diperlukan penegakan etika bagi akuntan publik, terlebih lagi setelah munculnya krisis kepercayaan 
tersebut. Dengan adanya penegakan etika, diharapkan mampu menghilangkan krisis kepercayaan masyarakat terhadap profesi akuntan publik.

Etika sebagai salah satu unsur utama dari profesi menjadi landasan bagi akuntan dalam menjalankan kegiatan profesional. Akuntan memiliki tanggung jawab untuk bertindak sesuai dengan kepentingan publik. Ikatan Akuntan Indonesia (IAI) sebagai organisasi akuntan di Indonesia telah memiliki Kode Etik IAI yang merupakan amanah dari AD/ART IAI dan peraturan yang berlaku, yaitu Keputusan Menteri Keuangan No. 263/KMK.01/2014 tentang Penetapan Ikatan Akuntan Indonesia Sebagai Organisasi Profesi Akuntan. Kode etik tersebut perlu untuk dimutakhirkan dengan perkembangan saat ini dan ketentuan kode etik akuntan profesional yang berlaku secara internasional.

\section{B. PRINSIP ETIKA PROFESI IKATAN AKUNTAN INDONESIA}

Untuk pertama kalinya, dalam kongres tahun 1973 IAI menetapkan kode etik bagi profesi akuntan di Indonesia, yang saat itu diberi nama Kode Etik Ikatan Akuntan Indonesia. Kode etik ini mengatur standar mutu terhadap pelaksanaan pekerjaan akuntan. Standar mutu ini penting untuk menjaga kepercayaan masyarakat terhadap profesi akuntan. Setelah mengalami perubahan, maka tahun 1998 Ikatan Akuntan Indonesia menetapkan delapan prinsip etika yang berlaku bagi seluruh anggota IAI baik di pusat maupun di daerah (IAI, 2001). 
Keanggotaan dalam Ikatan Akuntan Indonesia bersifat sukarela. Dengan menjadi anggota, seorang akuntan mempunyai kewajiban untuk menjaga disiplin di atas dan melebihi yang disyaratkan oleh hukum dan peraturan.

Prinsip Etika Profesi dalam Kode Etik IAI menyatakan pengakuan profesi akan tanggung jawabnya kepada publik, pemakai jasa akuntan, dan rekan. Prinsip ini memandu anggota dalam memenuhi tanggung jawab profesionalnya dan merupakan landasan dasar perilaku etika dan perilaku profesionalnya. Prinsip ini meminta komitmen untuk berperilaku terhormat, bahkan dengan pengorbanan keuntungan pribadi.

Kode Etik Ikatan Akuntan Indonesia dimaksudkan sebagai panduan dan aturan bagi seluruh anggota, baik yang berpraktik sebagai akuntan publik, bekerja di lingkungan dunia usaha, pada instansi pemerintah, maupun di lingkungan dunia pendidikan dalam pemenuhan tanggung-jawab profesionalnya.

Dari asal usul kata, Etika berasal dari bahasa Yunani 'ethos' yang berarti adat istiadat/ kebiasaan yang baik Perkembangan etika yaitu Studi tentang kebiasaan manusia berdasarkan kesepakatan, menurut ruang dan waktu yang berbeda, yang menggambarkan perangai manusia dalam kehidupan pada umumnya. Tujuan profesi akuntansi adalah memenuhi tanggungjawabnya dengan standar profesionalisme tertinggi, mencapai tingkat kinerja tertinggi, dengan orientasi kepada kepentingan 
publik. Untuk mencapai tujuan tersebut terdapat empat kebutuhan dasar yang harus dipenuhi:

1. Kredibilitas. Masyarakat membutuhkan kredibilitas informasi dan sistem informasi.

2. Profesionalisme. Diperlukan individu yang dengan jelas dapat diidentifikasikan oleh pemakai jasa Akuntan sebagai profesional di bidang akuntansi.

3. Kualitas Jasa. Terdapatnya keyakinan bahwa semua jasa yang diperoleh dari akuntan diberikan dengan standar kinerja tertinggi.

4. Kepercayaan. Pemakai jasa akuntan harus dapat merasa yakin bahwa terdapat kerangka etika profesional yang melandasi pemberian jasa oleh akuntan.

Kode Etik Ikatan Akuntan Indonesia terdiri dari tiga bagian: (1) Prinsip Etika, (2) Aturan Etika, dan (3) Interpretasi Aturan Etika. Prinsip Etika memberikan kerangka dasar bagi Aturan Etika, yang mengatur pelaksanaan pemberian jasa profesional oleh anggota. Prinsip Etika disahkan oleh Kongres dan berlaku bagi seluruh anggota, sedangkan Aturan Etika disahkan oleh Rapat Anggota Himpunan dan hanya mengikat anggota Himpunan yang bersangkutan. Interpretasi Aturan Etika merupakan interpretasi yang dikeluarkan oleh Badan yang dibentuk oleh Himpunan setelah memperhatikan tanggapan dari anggota, dan pihak-pihak berkepentingan lainnya, sebagai panduan dalam penerapan 
Aturan Etika, tanpa dimaksudkan untuk membatasi lingkup dan penerapannya. Kepatuhan terhadap Kode Etik, seperti juga dengan semua standar dalam masyarakat terbuka, tergantung terutama sekali pada pemahaman dan tindakan sukarela anggota. Di samping itu, kepatuhan anggota juga ditentukan oleh adanya pemaksaan oleh sesama anggota dan oleh opini publik, dan pada akhirnya oleh adanya mekanisme pemrosesan pelanggaran Kode Etik oleh organisasi, apabila diperlukan, terhadap anggota yang tidak menaatinya.Dalam hubungannya dengan akuntan publik, berdasarkan Jurnal Riset Akuntansi Indonesia (edisi 2001) menyatakan bahwa ada beberapa faktor yang memungkinkan berpengaruh terhadap sikap dan perilaku etis akuntan, termasuk akuntan publik. Faktor-faktor tersebut antara lain :

\section{Faktor Posisi / Kedudukan.}

Agoes dan Ardana (2014) menunjukkan bahwa semakin tinggi posisi / kedudukan di KAP (dalam hal ini Partner dan Manajer) cenderung memiliki pemikiran etis yang rendah, sehingga berakibat pada rendahnya sikap dan perilaku etis mereka.

\section{Faktor imbalan yang diterima ( berupa gaji / upah dan penghargaan /insentif)}

Pada dasarnya seseorang yang bekerja, mengharapkan imbalan yang sesuai dengan pekerjaannya. Karena dengan upah yang sesuai dengan pekerjaannya, maka akan timbul pula rasa gairah kerja yang semakin baik dan ada kecenderungan 
untuk bekerja secara jujur disebabkan ada rasa timbal balik yang selaras dan tercukupi kebutuhannnya. Selain gaji/upah, seseorang yang bekerja membutuhkan penghargaan atas hasil karya yang telah dilakukan, baik penghargaan yang bersifat materil maupun non materil. Jika ia mendapatkan penghargaan sesuai dengan karyanya maka si pekerja akan berbuat sesuai aturan kerja dalam rangka menjaga citra profesinya baik di dalam maupun diluar pekerjaannya .

\section{Faktor Pendidikan (Formal, Nonformal dan Informal)}

Arens (2008) menyatakan bahwa pendidikan akuntansi (pendidikan formal) mempunyai pengaruh yang besar terhadap perilaku etis akuntan publik.

Faktor organisasional (perilaku atasan, lingkungan kerja, budaya organisasi, hubungan dengan rekan kerja). Komitmen atasan merupakan wibawa dari profesi, bila atasan tidak memberi contoh yang baik pada bawahan maka akan menimbulkan sikap dan perilaku tidak baik dalam diri bawahan sebab ia merasa bahwa atasannya bukanlah pemimpin yang baik (Jusuf, 2008). Lingkungan kerja turut menjadi faktor yang mempengaruhi etika individu. Lingkungan kerja yang baik akan membawa pengaruh yang baik pula pada segala pihak, termasuk para pekerja, hasil pekerjaan dan perilakudi dalamnya.

\section{Faktor Lingkungan Keluarga}

Pada umumnya individu cenderung untuk memilih sikap yang konformis/ searah dengan sikap dan perilaku orang- 
orang yang dianggapnya penting (dalam hal ini anggota keluarga). Kecenderungan iniantara lain di motivasi oleh keinginan untuk berafiliasi dan keinginan untuk menghindari konflik. Jadi jika lingkungan keluarga bersikap dan berperilaku etis, maka yang muncul adalah sikap dan perilaku etis pula (Jusuf, 2001).

\section{Faktor Pengalaman Hidup}

Beberapa pengalaman hidup yang relevan dapat mempengaruhi sikap etis apabila pengalaman hidup tersebut meninggalkan kesan yang kuat. Apabila seseorang dapat mengambil pelajaran dari pengalamanmasa lalunya maka akan menumbuhkan sikap dan perilaku yang semakin etis .

\section{Faktor Religiusitas}

Agama sebagai suatu sistem, mempunyai pengaruh dalam pembentukan sikap karena ia meletakkan dasar konsep moral dalam individu. Setiapagama mengajarkan konsep sikap dan perilaku etis, yang menjadi stimulus dan dapat memperteguh sikap dan perilaku etis.

\section{Faktor Hukum (Sistem Hukum dan Sanksi yang Diberikan).}

Jusuf (2008), berpendapat bahwa hukum yang berlakupada suatu profesi hendaklah mengandung muatan etika agar anggota profesi merasa terayomi. Demikian halnya dengan sanksi yang dikenakan harus tegas dan jelas sehingga anggota cenderung tidak mengulang kesalahan yang sama dalam kesempatan yang berbeda.

\section{Faktor Emotional Quotient (EQ).}


EQ adalah bagaimana seseorang itu pandai mengendalikan perasaan dan emosi pada setiap kondisi yang melingkupinya. EQ lebih penting dari pada IQ. Bagaimanapun juga seseorang yang cerdas bukanlah hanya cerdas dalam hal intelektualnya saja, tetapi intelektualitas tanpa adanya EQ dapat melahirkan perilaku yang tidak etis (Agoes dan Ardana, 2014). Berdasarkan faktorfaktor di atas dapat disimpulkan bahwa sikap akan menentukan warna atau corak tingkah laku seorang untuk berperilaku etis dan tidak etis.

\section{Fungsi Etika :}

- Sarana untuk memperoleh orientasi kritis berhadapan dengan pelbagai moralitas yang membingungkan.

- Etika ingin menampilkanketrampilan intelektual yaitu ketrampilan untuk berargumentasi secara rasional dan kritis.

- Orientasi etis ini diperlukan dalam mengabil sikap yang wajar dalam suasana pluralisme.

\section{Faktor-faktor Yang Mempengaruhi Pelanggaran Etika :}

- Kebutuhan Individu

- Tidak Ada Pedoman

- Perilaku dan Kebiasaan Individu Yang Terakumulasi dan Tak Dikoreksi

- Lingkungan Yang Tidak Etis

- Perilaku Dari Komunitas 


\section{Sanksi Pelanggaran Etika :}

- Sanksi Sosial adalah Skala relatif kecil, dipahami sebagai kesalahan yangdapat 'dimaafkan'.

- Sanksi Hukum adalah Skala besar, merugikan hak pihak lain.

\section{Jenis-jenis Etika :}

- Etika umum yang berisi prinsip serta moral dasar .

- Etika khusus atau etika terapan yang berlaku khusus.

\section{Ada tiga prinsip dasar perilaku yang etis :}

- Hindari pelanggaran etika yang terlihat remeh. Meskipun tidak besar sekalipun, suatu ketika akan menyebabkan konsekuensi yang besar pada profesi.

- Pusatkan perhatian pada reputasi jangka panjang. Disini harus diingat bahwa reputasi adalah yang paling berharga, bukan sekadar keuntungan jangka pendek.

- Bersiaplah menghadapi konsekuensi yang kurang baik bila berpegang pada perilaku etis. Mungkin akuntan akan menghadapi masalah karier jika berpegang teguh pada etika. Namun sekali lagi, reputasi jauh lebih penting untuk dipertahankan.

\section{TANGGUNG JAWAB PROFESI}


Dalam melaksanakan tanggung jawabnya sebagai profesional, setiap anggota harus senantiasa menggunakan pertimbangan moral dan profesional dalam semua kegiatan yang dilakukannya. Sebagai profesional, anggota mempunyai peran penting dalam masyarakat. Sejalan dengan peran tersebut, anggota mempunyai tanggung jawab kepada semua pemakai jasa profesional mereka. Anggota juga harus selalu bertanggungjawab untuk bekerja sama dengan sesama anggota untuk mengembangkan profesi akuntansi, memelihara kepercayaan masyarakat dan menjalankan tanggung jawab profesi dalam mengatur dirinya sendiri.

Tanggungjawab etis seorang akuntan telah diatur dalam bentuk koda etik profesi yang harus dilakukan oleh setiap akuntan. Koda etik yang harus dijalankan tersebut ditetapkan oleh IAI untuk di Indonesia, AICPA untuk di Amerika, dan IFAC untuk di seluruh dunia.Tanggungjawab etis akuntan terdiri dari 6 prinsip utama yang paling dominan dan diharapkan menjadikan seorang akuntan benar-benar profesional yaitu prinsip tanggungjawab, kepentingan publik, integritas, objektivitas dan indepensi, kecermatan dan kehati-hatian, dan prinsip lingkup dan sifat jasa (Agoes dan Ardana, 2014).

\section{KEPENTINGAN PUBLIK}

Setiap anggota berkewajiban untuk senantiasa bertindak dalam kerangka pelayanan kepada publik, menghormati 
kepercayaan publik, dan menunjukan komitmen atas profesionalisme. Satu ciri utama dari suatu profesi adalah penerimaan tanggung jawab kepada publik. Profesi akuntan memegang peran yang penting di masyarakat, dimana publik dari profesi akuntan yang terdiri dari klien, pemberi kredit, pemerintah, pemberi kerja, pegawai, investor, dunia bisnis dan keuangan, dan pihak lainnya bergantung kepada obyektivitas dan integritas akuntan dalam memelihara berjalannya fungsi bisnis secara tertib. Ketergantungan ini menimbulkan tanggung jawab akuntan terhadap kepentingan publik (Agoes dan Ardana, 2014).

Kepentingan publik didefinisikan sebagai kepentingan masyarakat dan institusi yang dilayani anggota secara keseluruhan. Ketergantungan ini menyebabkan sikap dan tingkah laku akuntan dalam menyediakan jasanya mempengaruhi kesejahteraan ekonomi masyarakat dan negara. Kepentingan utama profesi akuntan adalah untuk membuat pemakai jasa akuntan paham bahwa jasa akuntan dilakukan dengan tingkat prestasi tertinggi sesuai dengan persyaratan etika yang diperlukan untuk mencapai tingkat prestasi tersebut. Dan semua anggota mengikat dirinya untuk menghormati kepercayaan publik. Atas kepercayaan yang diberikan publik kepadanya, anggota harus secara terus menerus menunjukkan dedikasi mereka untuk mencapai profesionalisme yang tinggi.

\section{E. INTEGRITAS}


Untuk memelihara dan meningkatkan kepercayaan publik, setiap anggota harus memenuhi tanggung jawab profesionalnya dengan integritas setinggi mungkin. Integritas adalah suatu elemen karakter yang mendasari timbulnya pengakuan profesional. Integritas merupakan kualitas yang melandasi kepercayaan publik dan merupakan patokan (benchmark) bagi anggota dalam menguji keputusan yang diambilnya. Integritas mengharuskan seorang anggota untuk, antara lain, bersikap jujur dan berterus terang tanpa harus mengorbankan rahasia penerima jasa. Pelayanan dan kepercayaan publik tidak boleh dikalahkan oleh keuntungan pribadi. Integritas dapat menerima kesalahan yang tidak disengaja dan perbedaan pendapat yang jujur, tetapi tidak menerima kecurangan atau peniadaan prinsip.Untuk memelihara dan meningkatkan kepercayaan publik, setiap anggota harus memenuhi tanggung jawab profesionalnya dengan integritas setinggi mungkin (Agoes, 2004).

a. Integritas adalah suatu elemen karakter yang mendasari timbulnya pengakuan profesional.

b. Integritas mengharuskan seorang anggota untuk, antara lain, bersikap jujur dan berterus terang tanpa harus mengorbankan rahasia penerima jasa. Pelayanan dan kepercayaan publik tidak boleh dikalahkan oleh keuntungan pribadi. Integritas dapat menerima kesalahan yang tidak disengaja dan perbedaan pendapat yang jujur, tetapi tidak dapat menerima kecurangan atau peniadaan prinsip. 
c. Integritas mengharuskan seorang anggota untuk, antara lain, bersikap jujur dan berterus terang tanpa harus mengorbankan rahasia penerima jasa. Pelayanan dan kepercayaan publik tidak boleh dikalahkan oleh keuntungan pribadi. Integritas dapat menerima kesalahan yang tidak disengaja dan perbedaan pendapat yang jujur, tetapi tidak dapat menerima kecurangan atau peniadaan prinsip.

d. Integritas juga mengharuskan anggota untuk mengikuti prinsip obyektivitas dan kehati-hatian profesional.

\section{F. OBJEKTIVITAS}

Setiap anggota harus menjaga obyektivitasnya dan bebas dari benturan kepentingan dalam pemenuhan kewajiban profesionalnya. Obyektivitasnya adalah suatu kualitas yang memberikan nilai atas jasa yang diberikan anggota. Prinsip obyektivitas mengharuskan anggota bersikap adil, tidak memihak, jujur secara intelektual, tidak berprasangka atau bias, serta bebas dari benturan kepentingan atau dibawah pengaruh pihak lain. Anggota bekerja dalam berbagai kapasitas yang berbeda dan harus menunjukkan obyektivitas mereka dalam berbagai situasi. Anggota dalam praktek publik memberikan jasa atestasi, perpajakan, serta konsultasi manajemen. Anggota yang lain menyiapkan laporan keuangan sebagai seorang bawahan, melakukan jasa audit internal dan bekerja dalam kapasitas 
keuangan dan manajemennya di industri, pendidikan, dan pemerintah.

Mereka juga mendidik dan melatih orang orang yang ingin masuk kedalam profesi. Apapun jasa dan kapasitasnya, anggota harus melindungi integritas pekerjaannya dan memelihara obyektivitas.Setiap anggota harus menjaga obyektivitasnya dan bebas dari benturan kepentingan dalam pemenuhan kewajiban profesionalnya (Agoes, 2004).

1. Obyektivitas adalah suatu pemberian kualitas nilai dengan poin yang berdasarkan peraturan dengan bersikap adil, tidak memihak, jujur secara intelektual, tidak berprasangka atau bias, serta bebas dari benturan kepentingan atau berada di bawah pengaruh pihak lain.

2. Anggota bekerja dalam berbagai kapasitas yang berbeda dan harus menunjukkan obyektivitas mereka dalam berbagai situasi. Anggota dalam praktik publik memberikan jasa atestasi, perpajakan, serta konsultasi manajemen. Anggota yang lain menyiapkan laporan keuangan sebagai seorang bawahan, melakukan jasa audit internal dan bekerja dalam kapasitas keuangan dan manajemennya di industri, pendidikan dan pemerintahan.

3. Dalam menghadapi situasi dan praktik yang spesifik berhubungan dengan aturan etika sehubungan dengan obyektivitas, pertimbangan yang cukup harus diberikan terhadap faktor-faktor berikut: 
a) Obyektifitas tidak dapat diganggu dengan tekanan seperti situasi yangmemungkinkan mereka menerima tekanantekanan yang diberikan kepadanya.

b) Menyatakan dan menggambarkan semua situasi di mana tekanan-tekanan ini mungkin terjadi merupakan hal yang tidak praktis. Ukuran kewajaran (reasonableness) harus digunakan dalam menentukan standar untuk mengindentifikasi hubungan yang mungkin atau kelihatan dapat merusak obyektivitas anggota.

c) Hubungan-hubungan yang memungkinkan prasangka, bias atau pengaruh lainnya untuk melanggar obyektivitas harus dihindari.

d) Anggota memiliki kewajiban untuk memastikan bahwa orang-orang yang terilbat dalam pemberian jasa profesional mematuhi prinsip obyektivitas.

e) Anggota tidak boleh menerima atau menawarkan hadiah atau entertainment, hal ini dapat menimbulkan pengaruh yang tidak pantas terhadap pertimbangan profesional mereka atau terhadap orang-orang yang berhubungan dengan mereka. Anggota harus menghindari situasi-situasi yang dapat membuat posisi profesional mereka ternoda.

\section{G. KOMPETENSI DAN KEHATI-HATIAN PROFESIONAL}

Setiap anggota harus melaksanakan jasa profesionalnya dengan berhati-hati, kompetensi dan ketekunan, serta mempunyai 
kewajiban untuk mempertahankan pengetahuan dan ketrampilan profesional pada tingkat yang diperlukan untuk memastikan bahwa klien atau pemberi kerja memperoleh manfaat dari jasa profesional dan teknik yang paling mutakhir. Hal ini mengandung arti bahwa anggota mempunyai kewajiban untuk melaksanakan jasa profesional dengan sebaik-baiknya sesuai dengan kemampuannya, demi kepentingan pengguna jasa dan konsisten dengan tanggung jawab profesi kepada publik.

Kompetensi diperoleh melalui pendidikan dan pengalaman. Anggota seharusnya tidak menggambarkan dirinya memiliki keahlian atau pengalaman yang tidak mereka miliki. Kompetensi menunjukkan terdapatnya pencapaian dan pemeliharaan suatu tingkat pemahaman dan pengetahuan yang memungkinkan seorang anggota untuk memberikan jasa dengan kemudahan dan kecerdikan. Dalam hal penugasan profesional melebihi kompetensi anggota atau perusahaan, anggota wajib melakukan konsultasi atau menyerahkan klien kepada pihak lain yang lebih kompeten. Setiap anggota bertanggung jawab untuk menentukan kompetensi masing masing atau menilai apakah pendidikan, pedoman dan pertimbangan yang diperlukan memadai untuk bertanggung jawab yang harus dipenuhinya(Agoes, 2004).

\section{H. KERAHASIAAN}


Setiap anggota harus menghormati kerahasiaan informasi yang diperoleh selama melakukan jasa profesional dan tidak boleh memakai atau mengungkapkan informasi tersebut tanpa persetujuan, kecuali bila ada hak atau kewajiban profesional atau hukum untuk mengungkapkannya. Kepentingan umum dan profesi menuntut bahwa standar profesi yang berhubungan dengan kerahasiaan didefinisikan bahwa terdapat panduan mengenai sifat sifat dan luas kewajiban kerahasiaan serta mengenai berbagai keadaan di mana informasi yang diperoleh selama melakukan jasa profesional dapat atau perlu diungkapkan. Anggota mempunyai kewajiban untuk menghormati kerahasiaan informasi tentang klien atau pemberi kerja yang diperoleh melalui jasa profesional yang diberikannya. Kewajiban kerahasiaan berlanjut bahkan setelah hubungan antar anggota dan klien atau pemberi jasa berakhir. Berikut ini adalah contoh hal-hal yang harus dipertimbangkan dalam menentukan sejauh mana informasi rahasia dapat diungkapkan.

1. Apabila pengungkapan diizinkan. Jika persetujuan untuk mengungkapkan diberikan oleh penerima jasa, kepentingan semua pihak termasuk pihak ketiga yang kepentingannya dapat terpengaruh harus dipertimbangkan.

2. Pengungkapan diharuskan oleh hukum.

3. Ketika ada kewajiban atau hak profesional untuk mengungkapkan: 
4. untuk mematuhi standar teknis dan aturan etika; pengungkapan seperti itu tidak bertentangan dengan prinsip etika ini;untuk melindungi kepentingan profesional anggota dalam sidang pengadilan;untuk menaati peneleahan mutu (atau penelaahan sejawat) IAI atau badan profesionallainnya; dan untuk menanggapi permintaan atau investigasi oleh IAI atau badan pengatur (IAI, 2001).

\section{PERILAKU PROFESIONAL}

Menurut Ikatan Akuntan Indonesia (2001) setiap anggota harus berperilaku yang konsisten dengan reputasi profesi yang baik dan menjauhi tindakan yang dapat mendiskreditkan profesi. Kewajiban untuk menjauhi tingkah laku yang dapat mendiskreditkan profesi harus dipenuhi oleh anggota sebagai perwujudan tanggung jawabnya kepada penerima jasa, pihak ketiga, anggota yang lain, staf, pemberi kerja dan masyarakat umum.

\section{J. STANDAR TEKNIS}

Setiap anggota harus melaksanakan jasa profesionalnya sesuai dengan standar teknis dan standar profesional yang relevan. Sesuai dengan keahliannya dan dengan berhati-hati, anggota mempunyai kewajiban untuk melaksanakan penugasan dari penerima jasa selama penugasan tersebut sejalan dengan prinsip integritas dan obyektivitas (IAI, 2001). 
a. Standar teknis dan standar professional yang harus ditaati anggota adalah standar yang dikeluarkan oleh Ikatan Akuntan Indonesia. Internasional Federation of Accountants, badan pengatur, dan pengaturan perundang-undangan yang relevan.

Kode Etik Teknisi terdiri dari tiga bagian :

1. Prinsip Etika,

2. Aturan Etika,

3. Interprestasi Aturan Etika.

Prinsip Etika memberikan kerangka dasar bagi Aturan Etika, yang mengatur pelaksanaan pemberi jasa pofesional oleh anggota. Prinsip Etika disahkan dan berlaku bagi seluruh anggota, sedangkan Aturan Etika disahkan dan hanya mengikat anggota Himpunan yang bersangkutan. Interpretasi Aturan Etika merupakan interpretasi yang dikeluarkan oleh Badan yang dibentuk oleh Himpunan setelah memperhatikan tanggapan dari anggota, dan pihak-pihak berkepentingan lainnya, sebagai panduan dalam menerapkan Aturan Etiks, tanpa dimaksudkan untuk membatasi lingkup dan penerapannya.

Pernyataan Etika Profesi yang berlaku saat ini dapat dipakai sebagai aturan etika sampai dikeluarkannya aturan aturan baru untuk menggantikannya. Standar teknis dan standar professional yang harus ditaati anggota adalah standar yang dikeluarkan oleh Ikatan Akuntan Indonesia. Internasional 
Federation of Accountants, badan pengatur, dan pengaturan perundang-undangan yang relevan.

\section{DAFTAR PUSTAKA}

Agoes, Sukrisno. 2004. Auditing (PemeriksaanAkuntan) oleh Kantor Akuntan Pubik. Edisi ketiga. Jakarta: Lembaga Penerbit Fakultas Ekonomi Universitas Indonesia

Agoes, Sukrisno dan I Cenik Ardana. 2014. Etika Bisnis dan Profesi: Tantangan Membangun Manusia Seutuhnya. Jakarta. Penerbit: Salemba Empat

Arens, Alvin A. Randal J.Elder, Mark S.Beasley. 2008. Auditing and Assurance Services and ACL Software.12 ${ }^{\text {th }}$ Edition. New Jersey : Prentice Hall.

Jusuf, Al Haryono. 2001. Auditing (Pengauditan), Cetakan Pertama. Yogyakarta: Bagian Penerbitan STIE - YKPN.

Ikatan Akuntan Indonesia. 2001. Standart Profesional Akuntan Pubik. Jakarta. Penerbit: Salemba Empat 


\section{BAB VII \\ ETIKA PROFESI AKUNTAN SEKTOR PUBLIK}

\section{TUJUAN INSTRUKSIONAL}

Dengan membaca bab ini, mahasiswa diharapkan mampu untuk :

1. Menjelaskan Pengertian Akuntansi Sektor Publik

2. Memahami Cakupan Bidang Utama Sektor Pubik

3. Menjelaskan Tentang Dimensi Akuntabilitas Publik

4. Menjelaskan Tentang Prinsip Etika bagi Akuntan Publik

\section{PENDAHULUAN}

Akuntabilitas publik menjadi landasan utama proses penyelenggaraan pemerintahan yang baik. Karena itu aparatur pemerintah harus mempertanggungjawabkan seluruh aktivitas dan pelaksanaan kerjanya kepada publik. Dalam konteks organisasi pemerintahan sendiri, akuntabilitas publik merupakan pemberian informasi atas aktivitas dan kinerja pemerintah kepada pihak-pihak yang berkepentingan. Penekanan utama akuntabilitas publik adalah pemberian informasi kepada publik dan konstituen lainnya yang menjadi pemangku kepentingan (stakeholder). Akuntabilitas publik juga terkait dengan kewajiban untuk menjelaskan dan menjawab pertanyaan mengenai apa yang telah, sedang, dan direncanakan akan dilakukan organisasi sektor publik

\section{PENGERTIAN AKUNTANSI SEKTOR PUBLIK}


Akuntansi adalah salah satu aktivitas jasa yang mencatat, mengklasifikasikan, dan melaporkan transaksi ekonomi yang pada akhirnya menghasilkan informasi keuangan yang dapat digunakan para pengguna baik eksternal maupun internal dalam proses pengambilan keputusan (Sujarweni, 2015).

Sektor publik ialah segala hal yang berkaitan dengan kepentingan publik dan tentang penyediaan barang serta jasa ang ditujukan untuk publik, dibayarkan melalui pajak dan pendapatan negara lainnya yang sudah diatur dalam hukum. Contoh: pendidikn, transportasi dan kesehatan (Agoes dan Ardana, 2014).

Jadi akuntansi sektor publik dapat didefinisikan sebagai aktivitas jasa yang terdiri dari mencatat, mengklasifikasikan, dan melaporkan transaksi ekonomi yang akhirnya akan menghasilkan suatu informasi keuangan yang dibutuhkan oleh pihak tertentu untuk pengambilan keputusan, yang diterapkan pada pengelolaan dana publik di lembaga - lembaga tinggi negara dan departemen dibawahnya, pemerintah daerah, LSM dan yayasan sosial maupun proyek - proyek kerjasama sektor publik dengan swasta.

\section{CAKUPAN BIDANG UTAMA AKUNTANSI SEKTOR PUBLIK}

Cakupan bidang utama Akuntansi sektor publik di Indonesia pada berbagai bidang yakni:
a. Akuntansi Pemerintahan Pusat
b. Akuntansi Pemerintahan Daerah
c. Akuntansi Desa 
d. Akuntansi Tempat Peribadatan: Masjid, Gereja, Pura dan Wihara

e. Akuntansi LSM

f. Akuntansi Yayasan

g. Akuntansi Pendidikan: Sekolah, Perguruan Tinggi

h. Akuntansi Kesehatan: Puskesmas, Rumah Sakit

\section{DIMENSI AKUNTABILITAS PUBLIK}

Dimensi akuntabilitas ada 5, yaitu (Syahrudin Rasul, 2002:11)

a. Akuntabilitas hukum dan kejujuran (accuntability for probity and legality) Akuntabilitas hukum dan kejujuran adalah akuntabilitas lembaga - lembaga publik untuk berperilaku jujur dalam bekerja dan mentaati ketentuan hukum yang berlaku. Penggunaan dana publik harus dilakukan secara benar dan telah mendapat otorisasi. Akuntabilitas hukum menjamin ditegakkannya supremasi hukum, sedangkan akuntabilitas kejujuran menjamin adanya praktik organisasi yang sehat.

b. Akuntabilitas manajerial. Akuntabilitas manajerial yang dapat juga diartikan sebagai akuntabilitas kinerja (performance accountability) adalah pertanggungjawaban untuk melakukan pengelolaan organisasi secara efektif dan efisien. 
c. Akuntabilitas program. Akuntabilitas program berkaitan dengan pertimbangan apakah tujuan yang ditetapkan dapat dicapai atau tidak, dan apakah organisasi telah mempertimbangkan alternatif program yang memberikan hasil yang optimal dengan biaya yang minimal. Programprogram organisasi hendaknya merupakan program yang bermutu dan mendukung strategi dalam pencapaian visi, misi dan tujuan organisasi. Lembaga publik harus mempertanggungjawabkan program yang telah dibuat sampai pada pelaksanaan program

d. Akuntabilitas kebijakan. Lembaga - lembaga publik hendaknya dapat mempertanggung jawabkan kebijakan yang telah ditetapkan dengan mempertimbangkan dampak dimasa depan. Dalam membuat kebijakan harus dipertimbangkan apa tujuan kebijakan tersebut, mengapa kebijakan itu dilakukan.

e. Akuntabilitas finansial. Akuntabilitas ini merupakan pertanggungjawaban lembaga lembaga publik untuk menggunakan dana publik (public money) secara ekonomis, efisien dan efektif, tidak ada pemborosan dan kebocoran dana, serta korupsi. Akuntabilitas financial ini sangat penting karena menjadi sorotan utama masyarakat. Akuntabilitas ini mengharuskan lembaga-lembaga publik untuk membuat laporan keuangan untuk menggambarkan 
kinerja financial organisasi kepada pihak luar maupun masyarakat.

\section{PRINSIP ETIKA PROFESI BAGI AKUNTAN PUBLIK}

Prinsip - Prinsip Etika menurut AICPA sebagai berikut :

a. Tanggung Jawab

Dalam melaksanakan tanggung jawab mereka sebagai professional, anggota harus menerapkan penilaian professional dan moral atas seluruh aktivitas yang mereka lakukan.

b. Kepentingan Umum

Anggota harus menerima kewajiban mereka untuk bertindak dengan cara yang dapat melayani kepentingan publik, menghormati kepercayaan publik, dan menunjukkan komitmen pada profesionalisme.

c. Integritas

Untuk mempertahankan dan memperluas kepercayaan masyarakat, anggota harus melakukan semua tanggung jawab professional dengan integritas tertinggi.

d. Objektivitas dan Independensi

Seorang anggota harus mempertahankan objectivitas dan bebas dari konflik kepentingan dalam melaksanakan tanggung jawab professional, serta harus independen dalam penyajian fakta dan tampilan ketika memberikan layanan audit dan jasa atestasi lainnya. 
e. Due Care

Seorang anggota harus mematuhi standar teknis dan etis profesi, berusaha terus menerus untuk menigkatkan kompetensi dan layanan dalam melaksanakan tanggung jawab professional dengan kemampuan terbaik yang dimiliki anggota.

f. Lingkup dan sifat jasa

Seorang anggota dalam praktik publik harus memerhatikan prinsip-prinsip dari Kode Etik Profesional dalam menentukan lingkup dan sifat jasa yang akan disediakan.

\section{DAFTAR PUSTAKA}

Agoes, Sukrisno dan I Cenik Ardana. 2014. Etika Bisnis dan Profesi: Tantangan Membangun Manusia Seutuhnya. Jakarta. Penerbit: Salemba Empat

Rasul, Syahrudin. 2003. Pengintegrasian Sistem Akuntabilitas Kinerja dan Anggaran dalam Perspektif UU NO. 17/2003 Tentang Keuangan Negara. Jakarta: PNRI

Sujarweni, V. Wiratna. 2015. Akuntansi Sektor Publik. Yogyakarta: Pustaka Baru Press https://www.kajianpustaka.com/2012/12/teori-akuntabilitas.html 



\section{BAB VIII}

\section{ETIKA PROFESI DALAM PRAKTIK AKUNTANSI MANAJEMEN \\ DAN AKUNTANSI KEUANGAN}

\section{TUJUAN INSTRUKSIONAL}

Dengan membaca bab ini, mahasiswa diharapkan mampu untuk :

1. Memahami Pengertian dan Lingkup Akuntansi Manajemen dan Keuangan

2. Menjelaskan Tanggung Jawab Manajemen

3. Menjelaskan Standar Kode Etik untuk Praktisi Akuntan Manajemen dan Manajemen Keuangan

\section{A. PENDAHULUAN}

Akuntansi manajemen merupakan disiplin ilmu yang berkenaan dengan penggunaan informasi akuntansi oleh para manajemen dan pihak-pihak internal lainnya untuk keperluan penghitungan biaya produk, perencanaan, pengendalian dan evaluasi, serta pengambilan keputusan manajemen. Umumnya informasi yang dihasilkan sifatnya lebih dalam dan biasanya tidak dipublikasikan. Sedangkan akuntansi keuangan dipublikasikan karena proyeksinya lebih untuk pengguna eksternal.

\section{B. PENGERTIAN DAN LINGKUP AKUNTANSI MANAJEMEN DAN KEUNGAN}


Akuntansi manajemen adalah proses identifikasi, pengukuran, analisis, penyiapan dan komunikasi informasi keuangan yang digunakan oleh manajemen untuk perencanaan , evaluasi, pengendalian dalam suatu organisasi serta untuk menjamin ketepatan pengunaan sumber-sumber dan pertanggungjawabannya. Akuntansi manajemen juga meliputi penyiapan laporan keuangan untuk kelompok non manajemen misalnya pemegang saham, parta kreditor, lembaga pengaturan dan penguasa perpajakan.

Hubungan Akuntansi Manajemen dengan Akuntansi Keuangan dan Akuntansi Biaya Menurut Mulyadi (2001 : 8) Akuntansi manajemen dan akuntansi keuangan mempunyai hubungan yang erat satu sama lain, yaitu :

Yang pertama, prinsip akuntansi yang berterima umum dalam akuntansi keuangan kemungkinan besar juga merupakan prinsip pengukuran yang relevan dalam akuntansi manajemen. Sebagai contoh, akuntansi keuangan menganut prinsip penandingan pendapatan dan biaya yang bersangkutan dengan pendapatan tersebut dalam menghitung laba yang diperoleh perusahaan dalam periode tertentu.

Sedangkan menurut Rudianto (2006:4): “Akuntansi manajemen merupakan sistem alat, yakni jenis yang informasi yang dihasilkannya ditujukan kepada pihak- pihak internal organisasi, seperti manajer keuangan, manajer produksi, manajer 
pemasaran dan sebagainya guna pengambilan keputusan internal organisasi.

Defenisi akuntansi manajemen yang dikemukakan oleh Management Accounting Practices Committee (MAPC) yang dibentuk National Association of Accountants (NAA) yang dikutip oleh Supriyono (2001: 3) yang berbunyi sebagai berikut:

Akuntansi manajemen adalah proses identifikasi, pengukuran, analisis, penyiapan dan komunikasi informasi keuangan yang digunakan oleh manajemen untuk perencanaan , evaluasi, pengendalian dalam suatu organisasi serta untuk menjamin ketepatan pengunaan sumber-sumber dan pertanggungjawabannya. Akuntansi manajemen juga meliputi penyiapan laporan keuangan untuk kelompok non manajemen misalnya pemegang saham, parta kreditor, lembaga pengaturan dan penguasa perpajakan.

Akuntansi keuangan merupakan bidang akuntansi yang mengkhususkan fungsi dan aktivitasnya pada kegiatan pengolahan data akuntansi dari suatu perusahaan dan penyusunan laporan keuangan untuk memenuhi kebutuhan berbagai pihak, yaitu pihak internal dan eksternal. OKI, tujuan akuntansi keuangan adalah menyediakan informasi kepada pihak yang berkepentingan, maka laporan keuangan harus bersifat umum sehingga dapat diterima oleh semua pihak yang berkepentingan.

Perbedaan pokok antara akuntansi manajemen dan akuntansi keuangan menurut Halim dan Supomo (2005: 11) yaitu: 
1. Pemakai Informasi: akuntansi keuangan menyajikan informasi keuangan terutama untuk pihak eksternal perusahaan (kreditur, pemerintah, investor, serikat pekerja, dan lain-lain), sedangkan akuntansi manajemen terutama untuk manajemen (pihak internal) perusahaan.

2. Dasar Penyajian Informasi: Informasi akuntansi keuangan disajikan berdasarkan prinsip-prinsip akuntansi yang diterima umum, sedangkan penyajian informasi akuntansi manajemen tidak terikat oleh prinsip-prinsip akuntansi yang diterima umum. Akuntansi manajemen tidak ada yang mendasari, dalam arti tidak ada pihak manapun yang mengatur bagaimana informasi akuntansi manajemen harus disajikan. Bagi akuntansi manajemen yang lebih penting adalah manfaat informasi tersebut, bukan masalah kesesuaiannya dengan prinsip akuntansi.

3. Fokus Informasi: Informasi akuntansi keuangan menggambarkan tentang posisi dan kemampuan keuangan perusahaan secara keseluruhan sebagai kesatuan unit usaha, sedangkan akuntansi manajemen memberika informasi keuangan dari bagian-bagian didalam perusahaan.

4. Orientasi Informasi: Informasi akuntansi keuangan hanya mencakup data masa lalu, sedangkan akuntansi manajemen memberikan informasi yang mencakup data masa lalu dan data masa yang akan datang. 
5. Tipe Informasi: Informasi akuntansi keuangan terutama merupakan informasi yang dinyatakan dengan satuan uang (moneter), sedangkan informasi akuntansi manajemen mencakup informasi moneter maupun non moneter.

6. Ketetapan Informasi: Informasi yang disajikan akuntansi keuangan lebih tepat dibandingkan dengan informasi akuntansi manajemen, karena periode penyusunan informasi akuntansi keuangan relatif lebih panjang dibandingkan dengan periode penyusunan informasi akuntansi manajemen yang lebih menekankan ketepatan waktu bukan ketepatan data. Bahkan, agar informasi tidak terlambat, akuntansi manajemen menggunakan data taksiran.

\section{TANGGUNG JAWAB MANAJEMEN}

Akuntansi manajemen adalah disiplin ilmu yang berkenaan dengan penggunaan informasi akuntansi oleh para manajemen dan pihak-pihak internal lainnya untuk keperluan penghitungan biaya produk, perencanaan, pengendalian dan evaluasi, serta pengambilan keputusan. Definisi akuntansi manajemen menurut Chartered Institute of Management Accountant, yaitu Penyatuan bagian manajemen yang mencakup, penyajian dan penafsiran informasi yang digunakan untuk perumusan strategi, aktivitas perencanaan dan pengendalian, pembuatan keputusan, optimalisasi penggunaan sumber daya, pengungkapan kepada pemilik dan pihak luar, pengungkapan kepada pekerja. Akuntan 
manajemen mempunyai peran penting dalam menunjang tercapainya tujuan perusahaan, dimana tujuan tersebut harus dicapai melalui cara yang legal dan etis, maka para akuntan manajemen dituntut untuk bertindak jujur, terpercaya, dan etis.

Tanggung jawab yang dimiliki oleh seorang akuntan manajemen lebih luas dibandingkan tanggung jawab seorang akuntan keuangan, yaitu:

a) Perencanaan

Menyusun dan berpartisipasi dalam mengembangkan sistem perencanaan, menyusun sasaran-sasaran yang diharapkan, dan memilih cara-cara yang tepat untuk memonitor arah kemajuan dalam pencapaian sasaran.

b) Pengevaluasian

Mempertimbangkan implikasi-implikasi historical dan kejadiankejadian yang diharapkan, serta membantu memilih cara terbaik untuk bertindak.

c) Pengendalian

Menjamin integritas informasi finansial yang berhubungan dengan aktivitas organisasi dan sumber-sumbernya, memonitor dan mengukur prestasi, dan mengadakan tindakan koreksi yang diperlukan untuk mengembalikan kegiatan pada cara-cara yang diharapkan.

d) Menjamin pertanggungjawaban sumber

Mengimplementasikan suatu sistem pelaporan yang disesuaikan dengan pusat-pusat pertanggungjawaban dalam 
suatu organisasi sehingga sistem pelaporan tersebut dapat memberikan kontribusi kepada efektifitas penggunaan sumber daya dan pengukuran prestasi manajemen.

e) Pelaporan eksternal

Ikut berpartisipasi dalam proses mengembangkan prinsipprinsip akuntansi yang mendasari pelaporan eksternal.

\section{STANDAR KODE ETIK UNTUK PRAKTISI AKUNTAN}

\section{MANAJEMEN DAN MANAJEMEN KEUANGAN}

Ikatan Akuntan Manajemen (Institute of Management Accountant - IMA) di Amerika Serikat telah mengembangkan kode etik yang disebut Standar Kode Etik untuk Praktisi Akuntan Manajemen dan Manajemen Keuangan (Standards of Ethical Conduct for Practitioners of Management Accounting and Financial Management).

Ada empat standar etika untuk akuntan manajemen yaitu:

1. Kompetensi

Artinya, akuntan harus memelihara pengetahuan dan keahlian yang sepantasnya, mengikuti hukum, peraturan dan standar teknis, dan membuat laporan yang jelas dan lengkap berdasarkan informasi yang dapat dipercaya dan relevan.

Praktisi manajemen akuntansi dan manajemen keuangan memiliki tanggung jawab untuk:

Menjaga tingkat kompetensi profesional sesuai dengan pembangunan berkelanjutan, pengetahuan dan keterampilan yang dimiliki. Melakukan tugas sesuai dengan hukum, peraturan dan 
standar teknis yang berlaku. Mampu menyiapkan laporan yang lengkap, jelas, dengan informasi yang relevan serta dapat diandalkan.

2. Kerahasiaan (Confidentiality)

Mengharuskan seorang akuntan manajemen untuk tidak mengungkapkan informasi rahasia kecuali ada otorisasi dan hukum yang mengharuskan untuk melakukan hal tersebut.

Praktisi manajemen akuntansi dan manajemen keuangan memiliki tanggung jawab untuk:

Mampu menahan diri dari mengungkapkan informasi rahasia yang diperoleh dalam pekerjaan, kecuali ada izin dari atasan atau atas dasar kewajiban hukum. Menginformasikan kepada bawahan mengenai kerahasiaan informasi yang diperoleh, agar dapat menghindari bocornya rahasia perusahaan. Hal ini dilakukan juga untuk menjaga pemeliharaan kerahasiaan.

Menghindari diri dari mengungkapkan informasi yang diperoleh untuk kepentingan pribadi maupun kelompok secara ilegal melalui pihak ketiga.

\section{Integritas (Integrity)}

Mengharuskan untuk menghindari "conflicts of interest", menghindari kegiatan yang dapat menimbulkan prasangka terhadap kemampuan mereka dalam menjunjung etika.

Praktisi manajemen akuntansi dan manajemen keuangan memiliki tanggung jawab untuk: 
Menghindari adanya konflik akrual dan menyarankan semua pihak agar terhindar dari potensi konflik. Menahan diri dari agar tidak terlibat dalam kegiatan apapun yang akan mengurangi kemampuan mereka dalam menjalankan tigas secara etis. Menolak berbagai hadiah, bantuan, atau bentuk sogokan lain yang dapat mempengaruhi tindakan mereka.

Menahan diri dari aktivitas negati yang dapat menghalangi dalam pencapaian tujuan organisasi. Mampu mengenali dan mengatasi keterbatasan profesional atau kendala lain yang dapat menghalagi penilaian tanggung jawab kinerja dari suatu kegiatan. Mengkomunikasikan informasi yang tidak menguntungkan serta yang menguntungkan dalam penilaian profesional. Menahan diri agar tidak terlibat dalam aktivitas apapun yang akan mendiskreditkan profesi.

4. Objektivitas (Objectifity)

Mengharuskan para akuntan untuk mengkomunikasikan informasi secara wajar dan objektif, mengungkapan secara penuh (fully disclose) semua informasi relevan yang diharapkan dapat mempengaruhi pemahaman user terhadap pelaporan, komentar dan rekomendasi yang ditampilkan.

Praktisi manajemen akuntansi dan manajemen keuangan memiliki tanggung jawab untuk:

Mengkomunikasikan atau menyebarkan informasi yang cukup dan objektif. 
Mengungkapkan semua informasi relevan yang diharapkan dapat memberikan pemahaman akan laporan atau rekomendasi yang disampaikan.

\section{DAFTAR PUSTAKA}

Halim, Abdul dan Bambang Supomo, 2005. Akuntansi Manajemen, Edisi 1, Cetakan Kesebelas, BPFE, Yogyakarta.

Mulyadi, 2001. Akuntansi Manajemen. Edisi Ketiga. Cetakan Ketiga. Salemba Empat. Jakarta.

Rudianto, 2006. Akuntansi Manajemen : Informasi untuk Pengambilan Keputusan Manajemen, Editor Surya Ubha, Grasindo, Jakarta.

Supriyono, 2001. Akuntansi Manajemen, Edisi Kedua, Cetakan Pertama, BPFE, Yogyakarta.

Supriyono R. A, 2001. Akuntansi Biaya, Perencanaan Dan Pengendalian Biaya Serta Pembuatan Keputusan, Buku dua, Edisi Kedua, BPFE, Yogyakarta. 


\section{BAB IX}

\section{ETIKA PROFESI DALAM AKUNTANSI PERPAJAKAN}

\section{TUJUAN INSTRUKSIONAL}

Dengan membaca bab ini, mahasiswa diharapkan mampu untuk

1. Memahami Pengertian Akuntansi Perpajakan

2. Menjelaskan Tentang Kewajiban dan Hak Konsultan Pajak Indonesia

3. Menjelaskan Kode Etik Konsultan Pajak Indonesia

4. Menjelaskan Sanksi Atas Pelanggaran Kode Etik Profesi Konsultan Pajak

\section{A. PENDAHULUAN}

Akuntansi perpajakan merupakan salah satu cabang akuntasi yang mencatatat, menangani, menghitung, menganalisa dan membuat strategi perpajakan sehubungan dengan transaksi perusahaan yang berkaitan dengan pajak. Oleh sebab itu dalam sebuah perusahaan, fungsi akuntansi perpajakan sangat krusial karena jika salah dalam menentukan pajak, maka akan berakibat buruk untuk perusahaan tersebut. Salah satu akibatnya adalah izin usaha akan dicabut. Perusahaan dapat menggunakan jasa Konsultan Pajak untuk memberikan jasa konsultasi dibidang perpajakan sesuai dengan batasan tingkat keahlian yang dimilikinya pada Sertifikat Konsultan Pajak. 
Seorang konsultan pajak harus patuh terhadap Kode Etik IKPI sebagai kaidah moral yang menjadi pedoman dalam berfikir, bersikap dan bertindak bagi setiap anggota IKPI.

\section{B. PENGERTIAN AKUNTANSI PERPAJAKAN}

Secara umum akuntansi perpajakan (Tax Accounting) adalah suatu seni mencatatat, menggolongkan, mengikhtisarkan dan menafsirkan transaksi-tranksakti finansial yang dilaksanaan oleh perusahaan dengan tujuan menentukan jumlah penghasilan kena pajak yang diperoleh atau diterima dalam suatu tahun pajak guna sebagai dasar penetapan beban atau pajak penghasilan yang terutang oleh perusahaan sebagai wajib pajak.

Dalam hal ini wajib pajak adalah Wajib Pajak Badan dan Wajib Pajak Orang Pribadi. Definisi lain akuntansi perpajakan yaitu salah satu cabang akuntasi yang mencatatat, menangani, menghitung, menganalisa dan membuat strategi perpajakan sehubungan dengan transaksi perusahaan.

\section{FUNGSI, PRINSIP DAN PERANAN AKUNTANSI PERPAJAKAN}

Dalam sebuah perusahaan, fungsi akuntansi perpajakan sangat krusial karena jika salah dalam menentukan pajak, maka akan berakibat buruk untuk perusahaan tersebut. Salah satu akibatnya adalah izin usaha akan dicabut. Berikut ini adalah peranan dan fungsi dari akuntasi perpajakan dalam perusahaan, yaitu: 
1) Sebagai perancang strategi perpajakan yang harus dilakukan perusahaan, strateginya yang positif tetapi tidak melakukan suatu tindakan kecurangan atau penggelapan pajak.

2) Sebagai analisa dan prediksi nilai potensi pajak yang harus ditanggung atau dibayar oleh perusahaan.

3) Sebagai implementasi akuntansi terhadap setiap aktivitas perusahaan maka parlu menyiapkan dalam bentuk informasi laporan keuangan fiskal maupun dalam bentuk laporan keuangan komersial.

4) Sebagai dokumentasi perpajakan dengan baik dan untuk dijadikan bahan evaluasi.

Untuk mengolah data kuantitatif yang akan dipakai dalam menyajikan laporan keuangan yang berisi perhitungan perpajakan.

Untuk Prinsip akuntansi perpajakan dapat dibagi menjadi 5, yaitu:

1) Kesatuan Akuntansi

2) Kesatuan akuntasi dalam hal ini perusahaan dianggap sebagai satu kesatuan ekonomi yang terpisah dengan suatu pihak yang mempunyai kepentingan dengan sumber perusahaan.

3) Kesinambungan

4) Dalam prinsip ini bahwa suatu entitas ekonomi diasumsikan akan terus menerus melanjutkan usahanya dan tidak akan dibubarkan.

5) Harga Perturakaran Yang Objektif 
Peranan akuntansi perpajakan untuk perusahaan adalah sebagai berikut:

1) Membuat sebuah rencana dan strategi perpajakan

2) Memberikan analisan dan perkiraan suatu potensi pajak perusahaan di masa yang akan datang

3) Membuat arsip dan dokumentasi perpajakan dengan baik sebagai bahan melaksanakan pemeriksaan dan evaluasi

4) Menerapkan perlakuan akuntansi atas pajak dan bisa menyajikannya dalam sebuah laporan komersial ataupun fiskal perusahaan

Sifat akuntansi perpajakan adalah sebagai berikut:

Pajak merupakan iuran masyarakat kepada pemerintah yang bersifat dipaksa dalam membayarnya atau pembayarannya. Namun karena dipaksakan ini sering terjadi ketika petugas pajak berlaku semauanya atau tidak adil dalam menjalankan tugasnya. Ini bisa terjadi karena disebabkan dengan banyaknya para wajib pajak yang tidak menaati kewajiban dalam membayar pajak sebagaimana mestinya serta adanya kekeliruan saat mencatat transaksi perpajakan.

Pajak merupakan suatu alat yang penggunaanya untuk membiayai beban atau pengeluaran pemerintah, yang mana pemerintah dapat menggunakan pajak sebagai sumber kegiatan operasional pemerintahan. Para wajib pajak tidak menerima imbalan jasa secara langsung, tetapi wajib pajak mendapat 
perlindungan dari negaranya berupa pelayanan yang sesuai dengan haknya. Fungsi pajak adalah mengatur segala aspek ekonomi, sosial, dan budaya.

\section{KEWAJIBAN DAN HAK KONSULTAN PAJAK}

Seperti yang telah dijelaskan diatas Konsultan Pajak memiliki hak untuk memberikan jasa konsultasi dibidang perpajakan sesuai dengan batasan tingkat keahlian yang dimilikinya pada Sertifikat Konsultan Pajak. Konsultan Pajak juga memiliki kewajiban antara lain :

1) memberikan jasa konsultasi kepada Wajib Pajak dalam melaksanakan hak dan memenuhi kewajiban perpajakan sesuai dengan peraturan perundang-undangan perpajakan

2) mematuhi kode etik Konsultan Pajak dan berpedoman pada standar profesi Konsultan Pajak yang diterbitkan oleh Asosiasi Konsultan Pajak

3) mengikuti kegiatan pengembangan profesional berkelanjutan yang diselenggarakan atau diakui oleh Asosiasi Konsultan Pajak dan memenuhi satuan kredit pengembangan profesional berkelanjutan

4) menyampaikan laporan tahunan Konsultan Pajak dan

5) memberitahukan secara tertulis setiap perubahan pada nama dan alamat rumah dan kantor dengan melampirkan bukti perubahan dimaksud. 
Kewajiban untuk mengikuti kegiatan pengembangan profesional berkelanjutan dan memenuhi satuan kredit pengembangan profesional berkelanjutan pada huruf c diatas dihitung mulai bulan Januari tahun berikutnya setelah diterbitkannya Izin Praktik. Kegiatan pengembangan profesional berkelanjutan yang wajib diikuti oleh Konsultan Pajak terdiri atas:

1) pengembangan profesional berkelanjutan terstruktur, yaitu kegiatan pengembangan profesional berkelanjutan yang dilaksanakan Konsultan Pajak pada saat mengikuti konferensi, seminar, lokakarya, diskusi panel, pelatihan atau kursus dalam bidang perpajakan dan

2) pengembangan profesional berkelanjutan tidak terstruktur, yaitu kegiatan pengembangan profesional berkelanjutan yang dilaksanakan Konsultan Pajak pada saat berpartisipasi dalam kegiatan berorganisasi yang diselenggarakan oleh Asosiasi Konsultan Pajak.

Jumlah satuan kredit pengembangan profesional berkelanjutan yang wajib dipenuhi oleh Konsultan Pajak setiap tahun adalah sebagai berikut:

Konsultan Pajak dengan Sertifikat Konsultan Pajak tingkat A wajib mencapai 20 (dua puluh) satuan kredit pengembangan profesional berkelanjutan yang terdiri dari paling rendah 16 (enam belas) satuan kredit pengembangan profesional 
berkelanjutan terstruktur dan 4 (empat) satuan kredit pengembangan profesional berkelanjutan tidak terstruktur. Konsultan Pajak dengan Sertifikat Konsultan Pajak tingkat B wajib mencapai 40 (empat puluh) satuan kredit pengembangan profesional berkelanjutan yang terdiri dari paling rendah 32 (tigapuluh dua) satuan kredit pengembangan profesional berkelanjutan terstruktur dan 8 (delapan) satuan kredit pengembangan profesional berkelanjutan tidak terstruktur.

Konsultan Pajak dengan Sertifikat Konsultan Pajak tingkat C wajib mencapai 60 (enam puluh) satuan kredit pengembangan profesional berkelanjutan yang terdiri dari paling rendah 48 (empat puluh delapan) satuan kredit pengembangan profesional berkelanjutan.

\section{E. KODE ETIK KONSULTAN PAJAK INDONESIA}

Kode Etik IKPI adalah kaidah moral yang menjadi pedoman dalam berfikir, bersikap dan bertindak bagi setiap anggota IKPI. Setiap anggota IKPI wajib menjaga citra martabat profesi dengan senantiasa berpegang pada Kode Etik IKPI. Kode Etik IKPI juga mengatur sanksi terhadap tidak dipenuhinya kewajiban atau dilanggarnya larangan oleh anggota IKPI.

\section{F. SANKSI ATAS PELANGgARAN KODE ETIK PROFESI KONSULTAN PAJAK}

1. Sanksi terhadap pelanggaran Kode Etik berupa : 

a. Teguran tertulis;
b. Pemberhentian sementara;
c. Pemberhentian tetap;

2. Sebelum sanksi yang tersebut pada ayat (1) di atas diberikan, anggota IKPI yang bersangkutan harus diberi kesempatan membela diri dalam rapat Majelis Kehormatan dan anggota tersebut dapat disertai oleh sebanyak-banyaknya 3 (tiga) orang anggota IKPI lainnya sebagai pendamping.

3. Dalam hal keputusan sanksi pemberhentian tetap, maka keputusan tersebut baru berlaku setelah yang bersangkutan diberikan kesempatan untuk membela diri di depan Kongres.

4. Keputusan Kongres merupakan keputusan final dan mengikat.

\section{DAFTAR PUSTAKA}

Brooks J. Leonard. 2000. Business Professional Ethics for Accountant. Canada South-West Publishing.

Buchari Alma. 2009. Pengantar Bisnis. CV Alfabeta. Bandung Emil Bachtiar. 2012. Kasus-Kasus Etika Bisnis dan Profesi. Penerbit Salemba Empat. Jakarta.

Ikatan Akuntan Indonesia. 2015. Pernyataan Standar Akuntansi Keuangan. Penerbit Salemba Empat. Jakarta. 
Ikatan Akuntan Indonesia. 2015. Standar Profesional Akuntan Publik. Penerbit Salemba Empat. Jakarta.

Irham Fahmi. 2013. Etika Bisnis. Teori, Kasus, dan Solusi. Penerbit CV Alfabeta. Bandung.

Manuel G. Velasque. 2005. Etika Bisnis, Konsep dan Kasus. Edisi 5. Penerbit Andi. Yogyakarta

Maurice Jack. 1996. Accounting Ethics. London: Ptiman Publishing.

O.P Simorangkir. 2003. Etika Bisnis, Jabatan, dan Perbankan. PT Rineka Cipta. Jakarta.

Sony Keraf. 1998. Etika Bisnis, Tuntutan dan Relevansinya, Jakarta: Pustaka Filsafat.

Sukrisno Agoes dan I Cenik Ardana. 2009. Etika Bisnis dan Profesi. Tantangan Membangun Manusia Seutuhnya. Penerbit Salemba Empat. Jakarta. 


\section{BIODATA PENULIS}

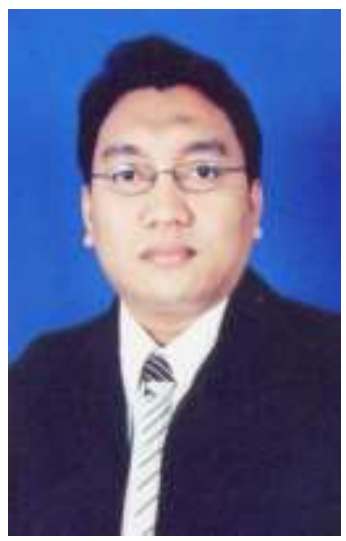

Dr. Sigit Hermawan, SE, M.Si, lahir di Bojonegoro, 03 Desember 1975. Penulis adalah Dosen PNS Kopertis Wilayah VII Jawa Timur Diperbantukan (DPK) pada Fakultas Ekonomi dan Bisnis Universitas Muhammadiyah Sidoarjo (UMSIDA) dengan Jabatan Fungsional Lektor Kepala. Penulis menyelesaikan Studi Strata 3 (S3) IImu Ekonomi Minat Akuntansi Fakultas Ekonomi dan Bisnis Universitas Airlangga Surabaya tahun 2012. Pendidikan S2 Magister Akuntansi diselesaikan di Universitas Airlangga Surabaya tahun 2004. Pengalaman melakukan penelitian dimulai dengan mengikuti hibah dosen muda Ditjen DIKTI Kemendiknas pada tahun 2005 sampai tahun 2007. Selanjutnya secara berturut-turut selama tiga tahun melakukan penelitian hibah bersaing Ditjen DIKTI Kemendikbud pada tahun 2008 - 2011. Pada tahun 2011 itu pula meraih penghargaan sebagai penyaji terbaik pada seminar hasil 
penelitian hibah BERSAING Ditjen DIKTI Kemendibud RI. Pada tahun 2011 - 2012 melakukan penelitian hibah PEKERTI Ditjen DIKTI Kemendikbud RI. Pada tahun 2014 - 2015 melakukan penelitian hibah FUNDAMENTAL dan pada tahun 2016 mendapat penghargaan sebagai penyaji terbaik pada seminar hasil riset dasar (FUNDAMENTAL) Ditjen Riset dan Pengabdian Pada Masyarakat Kemenristek Dikti. Berdasarkan banyaknya penelitian yang pernah dilakukan, penulis saat ini sebagai Reviewer Penelitian HibahHibah Yang Ada di Kemenristek DIKTI. Prestasi lain yang diperoleh adalah Best Paper Award dalam "Sosialisasi Pengelolaan Jurnal, Manajemen OJS, dan Kiat Penulisan Artikel IImiah" dari FEB Unibraw Malang pada tahun 2013. Dosen berpretasi Universitas Muhammadiyah Sidoarjo pada tahun 2013. Peraih The Best Paper Award dalam "The 1st International Joint Conference of Indonesia - Malaysia - Bangladesh - Ireland 2015", Universitas Ubudiyah Indonesia, Banda Aceh, 27 - 28 April 2015. Penulis juga sudah memiliki HAKI (Ciptaan) sebanyak dua buah dengan nomor 071732 dan 071735. Buku yang telah dihasilkan, yakni Metode Penelitian Kuantitatif dan Kualitatif (2016), Pusparagam Manajemen Indonesia (2011), Modul Manual dan Komputerisasi, Penyusunan laporan Anggaran Berbasis Kinerja dan Laporan Keuangan Sekolah (2009), Aplikasi Mudah dan Praktis MYOB Accounting Untuk Perusahaan Dagang (2008), Akuntansi Perusahaan Manufaktur (2008), dan Akuntansi Perusahaan Jasa (2006). 


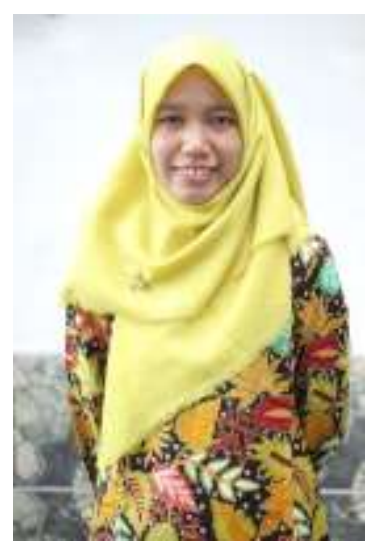

Nur Ravita Haun, SE, M.A, lahir di Surabaya, 26 Maret 1990. Penulis adalah Dosen pada Fakultas Ekonomi dan Bisnis Universitas Muhammadiyah Sidoarjo (UMSIDA). Penulis memperoleh beasiswa Alumni dari UMSIDA untuk melanjutkan studi S2 Magister Akuntansi di Universitas Airlangga Surabaya dan lulus tahun 2017 dengan predikat cumlaude. Aktif di berbagai organisasi yakni Nasyiatul Aisyiyah Daerah Sidoarjo sebagai Bendahara, Komunitas Peduli TBC sebagai Sekertaris serta Ketua Alumni FEB (IKAFE) UMSIDA. Pengalaman kerja sebagai Accounting CV Delta Rama (2012), Finance \& Accounting di Grup Bakrieland (2014). 